\title{
Hydrochemical and Isotopic Applications in the Western Aosta Valley (Italy) for Sustainable Groundwater Management
}

\author{
Barbara Grappein ${ }^{1}$, Manuela Lasagna ${ }^{1, *(\mathbb{D})}$, Pietro Capodaglio ${ }^{2}$, Chiara Caselle $^{1}(\mathbb{D}$ and \\ Domenico Antonio De Luca ${ }^{1}$ (D) \\ 1 Earth Sciences Department, Turin University, via Valperga Caluso 35, 10125 Turin, Italy; \\ barbara.grappein@edu.unito.it (B.G.); chiara.caselle@unito.it (C.C.); domenico.deluca@unito.it (D.A.D.L.) \\ 2 ARPA Valle d'Aosta, Sezione Suolo Rifiuti Energia, loc. La Maladière 48, Saint-Christophe, 11020 Aosta, Italy; \\ p.capodaglio@arpa.vda.it \\ * Correspondence: manuela.lasagna@unito.it
}

Citation: Grappein, B.; Lasagna, M.; Capodaglio, P.; Caselle, C.; De Luca, D.A. Hydrochemical and Isotopic Applications in the Western Aosta Valley (Italy) for Sustainable Groundwater Management. Sustainability 2021, 13, 487. https:// doi.org/10.3390/su13020487

Received: 25 November 2020 Accepted: 1 January 2021 Published: 6 January 2021

Publisher's Note: MDPI stays neutral with regard to jurisdictional clai$\mathrm{ms}$ in published maps and institutional affiliations.

Copyright: (C) 2021 by the authors. Licensee MDPI, Basel, Switzerland. This article is an open access article distributed under the terms and conditions of the Creative Commons Attribution (CC BY) license (https:// creativecommons.org/licenses/by/ $4.0 /)$.

\begin{abstract}
This research gives an overview of the status of water resources in the western Aosta Valley (Italy). Surface water, groundwater and precipitation were sampled during five sampling campaigns, and chemical analyses were performed and interpreted. Stable isotopes $\left(\delta^{18} \mathrm{O}\right.$ and $\left.\delta^{2} \mathrm{H}\right)$ were evaluated. This study highlights the relationships between water quality and quantity and local conditions (i.e., aquifer lithology, mixing into the aquifer, proximity to towns, contribution of snowmelt and ice melt to groundwater recharge, amount of rain, and season and altitude of the sampling location). A relationship between dust dispersed in the atmosphere as aerosols from the nearby Piedmont Region and the precipitation chemistry was identified, highlighting the presence of interregional conditions. Furthermore, isotopic analyses allowed the identification of aquifer feeding by both rainwater and glacial meltwater. Additionally, two origins for rainfall were identified: the Mediterranean Sea in winter and the Atlantic Ocean in summer. Finally, a local meteoric water line was calibrated for the study area. This research highlights the importance of implementing both traditional and isotopic techniques for water analysis to achieve optimal and sustainable management of water resources.
\end{abstract}

Keywords: groundwater quality; stable isotopes; alpine spring; surface water; rainfall; local meteoric water line; precipitation origin; Italy

\section{Introduction}

Water and groundwater availability are seriously affected by pollution, overexploitation and climate change [1-5]. As stated by the EU Water Framework Directive 2000/60, water protection must be a priority for each European country, and continuous monitoring is recommended to avoid serious contamination events and overexploitation of water resources.

The importance of water as an integral part of all human development and ecosystem needs is also emphasized in the Sustainable Development Goal SDG 6 [6]. More specifically, Goal 6 requires ensuring availability and sustainable management of water and sanitation for all people. According to the definition used in U.S. Geological Survey Circular 1186 [7], the sustainability of groundwater resources is the development and use of groundwater resources to meet current and future beneficial uses without causing unacceptable environmental or socioeconomic consequences.

To achieve Goal 6, broad and in-depth knowledge of the global dynamics of water use and availability is necessary. Thus, meaningful indicators are needed to assess sustainable water use and protection for humans and natural systems that consider both quantitative and qualitative aspects [8].

Correct exploitation and sustainable management of water resources are only possible with a deep knowledge of the complex dynamics that locally characterize the hydrological 
cycle. For this purpose, traditional monitoring techniques (i.e., groundwater analysis and piezometric level measurements) are insufficient. Relevant information on both the quality and quantity of water resources can be obtained, for example, from sampling and analysing the precipitation [9]. Furthermore, isotope hydrology can be used to establish the origin of rainfall [10] and other important information.

The purpose of this research was to provide an overview of the status of water resources in the western Aosta Valley (Italy) using both traditional and isotopic techniques. This multidisciplinary approach was extended to surface water, groundwater and precipitation, with the aim of filling the knowledge gap that is present due to a lack of investigation over the last 25 years. The main goal was to define the relationships between water quality status and space-time evolution in relation to the altitude, season, lithology, the interaction of human activities and wet air mass movement. A further objective was to define an updated local meteoric water line for the study area using isotopic precipitation data.

\section{Study Area}

The study area is located in the western part of the Aosta Valley (NW Italy) in an area between $614 \mathrm{~m}$ above sea level (a.s.l.) (the town of Sarre) and $4810 \mathrm{~m}$ a.s.l. (the town of Courmayeur, Mont Blanc).

The region is characterised by a wide primary valley floor developed in a west-east direction, with fluvial geomorphology, tributary valleys approximately orthogonal to the main valley floor, and a predominant glacial geomorphology. At the head of each valley, there are perennial glaciers. The region has a semi-continental alpine cold-temperate climate, with large daily and seasonal temperature variations; the maximum temperature was recorded in the summer at lower altitudes $\left(40.1^{\circ} \mathrm{C}\right.$, recorded in Saint-Christophe on 27 July 2019), and the minimum temperature was recorded in the winter at higher altitudes $\left(-36.6^{\circ} \mathrm{C}\right.$, recorded on Monte Bianco on 26-27 February 2018) [11]. Precipitation is usually scarce on the main valley floor $(<600 \mathrm{~mm} / \mathrm{y})$ and gradually increases with altitude (up to $1500 \mathrm{~mm} / \mathrm{y})$.

The western Aosta Valley, from a geological and structural point of view, is a highly articulated area. This valley developed across the most deformed sector of the Alpine chain and consists of three main structural domains (mainly the Penninic domain, the Helvetic domain, and peripherally, the Austroalpine domain [12]) (Figure 1, Table 1). Quaternary deposits are largely widespread in the study area. These deposits can be distinguished into glacial deposits, landslide deposits, slope deposits and alluvial deposits (listed in order from more to less diffuse).

Four hydrogeologic units can be recognized in the western Aosta Valley: (i) quaternary deposits unit, (ii) carbonate and evaporitic rocks unit, (iii) medium- to high-grade metamorphic rocks unit and (iv) intrusive igneous rocks unit.

The quaternary deposits have intergranular porosity. Metamorphic and igneous rocks have a fissure porosity, whereas the carbonate and evaporitic rocks unit, characterized by gypsum layers, carniole (carbonate rocks) and dolomites, shows fissure and karst (conduit) porosity.

The degree of permeability is high in the quaternary deposits. In particular, the alluvial deposits, located in correspondence with the main valley floors, have locally a high thickness (up to approximately $30 \mathrm{~m}$ in the Morgex area) and host relevant aquifers. 
Table 1. Geology of the area.

Domain Unit Subunit Main Lithology

Penninic

Piedmont Ophiolitic Unit

Combin$$
\text { Upper Zone- }
$$

Penninic

Internal Crystalline Massif

Gran Paradiso Unit

Penninic

Internal Zone

Penninic

Outer Zone

Helvetic
Ruitor Unit Houillère Unit
The ophiolitic units represent the relicts of the Jurassic Piemonte-Ligurian ocean. The Combin Unit is the upper unit of the Piedmont Zone (it is composed of the Zermatt-Saas Unit that preserves several eclogitic relicts and consists of different ophiolite complexes and the Combin Unit). It is composed of mainly metasediments, metabasite and metaophiolites with blueschist metamorphic imprinting and local preserved relicts of alpine eclogitic paragenesis $[13,14]$.

The Gran Paradiso Unit is one of the Internal Crystalline Massifs belonging to the Briançonnais Nappes system. This nappes system consists of several tectonic units of basement rocks and sedimentary cover $[15,16]$ and is characterized by different metamorphic evolutions within a range of greenschist to blueschist facies [17].

The Middle Penninic is represented by the Palaeozoic basement of the Gran San Bernard Nappe. This area consists of garnet micaschist and albitic paragneiss with some minor metabasite bodies and is covered by

discontinuous lower Mesozoic dolomitic metabreccia and marble [18,19].

The Ruitor Unit is composed of a polymetamorphic basement of prevailing micaschists and metabasites of Paleozoic age, with Ordovician intrusions [20]

$$
\text { The Houillère unit is a permo-carboniferous sequence. }
$$

The more external units of the Penninic Domain (i.e., the Valais units) were derived from the Valaisan Domain, a stretched area that for some authors

represents a narrow Cretaceous oceanic basin interposed between the

Briançonnais terrane and the European passive continental margin [21-23].

This area consists of a set of completely uprooted covering nappes with local ophiolites and few bedrock elements [24].

The Mt. Blanc Massif consists of coarse-grained granites and gneisses that form the basement of the Alps and once were part of the Mesozoic European middle crust. The Mt. Blanc Unit is one of the external crystalline massifs, which forms large dome-shaped structures surrounded by sedimentary rocks that once were deposited onto the Mesozoic European plate [25]. 


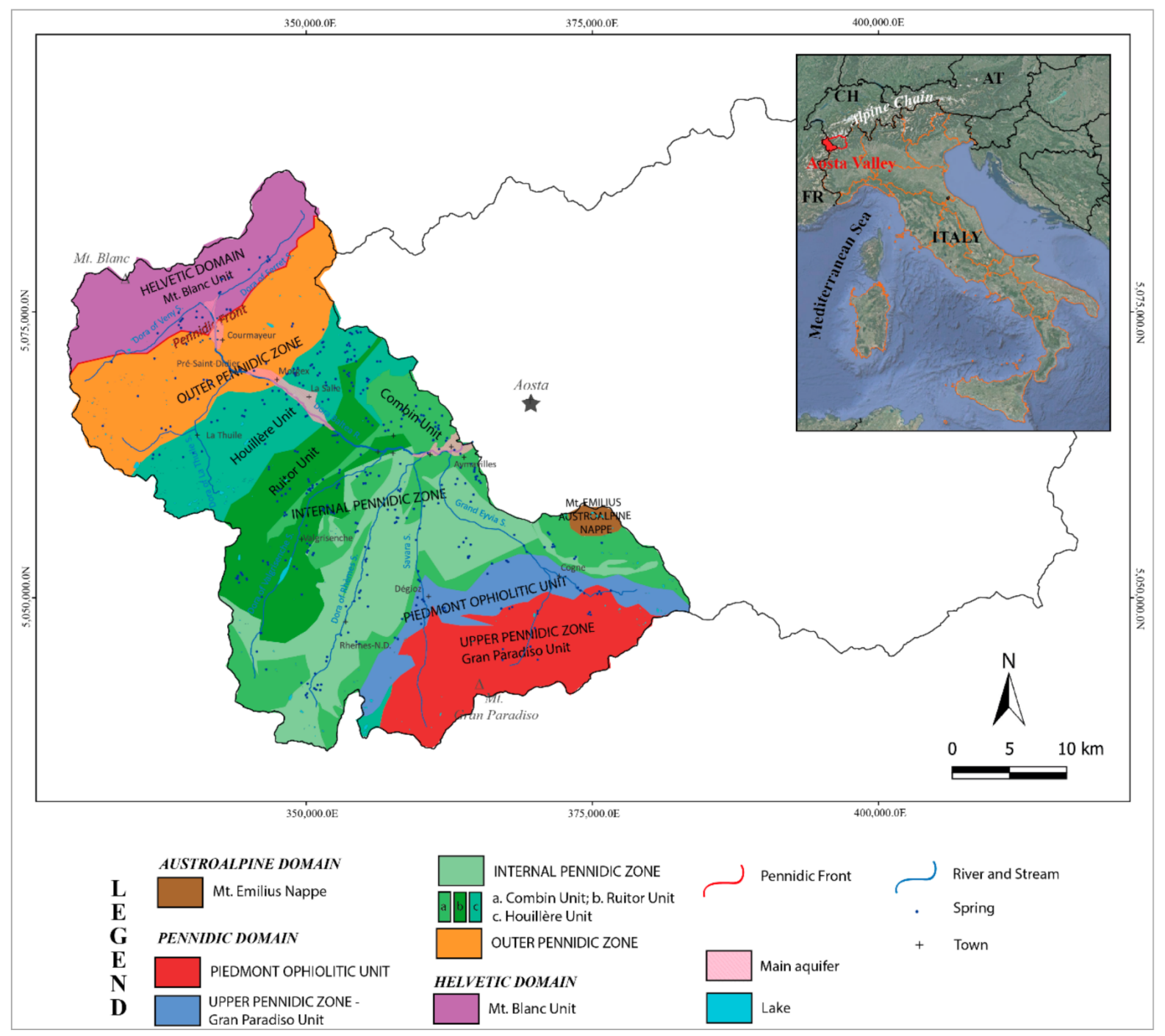

Figure 1. Synthetic geological map of the area. Quaternary deposits are not represented because of their widespread diffusion.

Lesser permeability degrees are found in carbonate and evaporitic rocks (high-medium permeability degree), then the medium- to high-grade metamorphic rocks unit (mediumvery low permeability degree), and lastly intrusive igneous rocks unit (low-very low permeability degree). Moreover, the degree of permeability of metamorphic and igneous rocks highly depends on the degree of rocks fracturing. The morphology of the area, which is heavily marked by previous glacial evolution and subsequent fluvial overprinting, directly affects the regional hydrology. The Dora Baltea River is one of the main tributary rivers (the fifth in terms of the flow rate) of the Po River and it is the only river in Italy with nival-glacial river flow. The Dora Baltea River basin, although generally characterised by an abundance of water due to the presence of high mountains and numerous glaciers, may occasionally suffer from quantitative water deficits, especially in the summer and during periods that see large influx of tourists [26]. The water quality of the river is generally good; however, anthropogenic activities along the main valley floor, the presence of towns and the under-sizing of water purification plants in combination with periods of heavy tourism locally affect the water quality.

The tributary streams are the drains of hanging valleys, and they flow into the Dora Baltea River. They generally have good quantitative and qualitative status. The diversions for both irrigation and hydroelectric use are few and controlled. 
Two main underground water bodies, the Courmayeur aquifer and the Morgex aquifer, which are close to the towns of Courmayeur and Morgex, respectively, are present in the study area, hosted in quaternary deposits along the main valley floor (Figure 1). These aquifers are monitored by the ARPA Valle d'Aosta (Aosta Valley Regional Agency for Environmental Protection) according to the EU Water Framework Directive 2000/60.

Since in the study area drinking water is provided by springs in mountains, and because there are no industrial activities, in both aquifers groundwater withdrawals from wells are almost absent; thus, without pressures, the quantitative status can be defined automatically as "good".

In the Morgex aquifer, chemical monitoring indicates a "good" chemical status without any exceedance of the concentration limits overseen by legislation. In the Courmayeur aquifer the qualitative status cannot yet be defined, mainly due to the poor density of monitoring points; however, local groundwater pollution (high conductivity values, sodium, chlorides and manganese) has been linked to the spreading of salt on roads in wintertime [27].

Wells drilled in alluvial aquifers [28] are concentrated in the Aosta plain, outside the study area, and are dedicated mainly to drinking and industrial purposes.

Approximately 1700 springs are present in the whole Aosta Valley, of which 500 are captured for drinking water purposes, making approximately 60,000 cubic metres of water available daily. Springs are widely distributed throughout the territory and are usually located in contact zones between quaternary deposits and bedrock [29] (Figure 1).

\section{Previous Isotopic Studies in the Study Area}

Stable water isotope analysis $\left(\delta^{18} \mathrm{O}\right.$ and $\left.\delta^{2} \mathrm{H}\right)$ provides important information about the origin of precipitation and the types of water feeding aquifers and rivers. Several papers have studied the isotopic composition of oxygen and hydrogen in Italy and in the Mediterranean area and have mainly analysed precipitation; all studies conducted in the Italian territory prior to 2016 were collected and listed by [30]. In particular, Longinelli and Selmo [31] described the isotopic compositions of oxygen and hydrogen nationwide by collecting and analysing samples from over 70 sampling stations located all over Italy. This study permitted us to define the vertical isotopic gradient of $\delta^{18} \mathrm{O}$ for the national territory as equal to $-0.2 \%$ o $/ 100$ and to formulate four local meteoric water line (LMWL) equations for Italy, northern Italy, central Italy and southern Italy (Table 2).

Table 2. Local meteoric water lines (LMWLs) formulated by [31].

\begin{tabular}{cc}
\hline Area & Equation \\
\hline Italy & $\delta \mathrm{D}=7.61 \delta^{18} \mathrm{O}+9.21$ \\
\hline Northern Italy & $\delta \mathrm{D}=7.7094 \delta^{18} \mathrm{O}+9.4034$ \\
\hline Central Italy & $\delta \mathrm{D}=7.0479 \delta^{18} \mathrm{O}+5.608$ \\
\hline Southern Italy & $\delta \mathrm{D}=6.97 \delta^{18} \mathrm{O}+7.3165$ \\
\hline
\end{tabular}

Giustini et al. [30] analysed isotopes of samples from 266 rain gauges throughout the national territory to study the spatial variability of $\delta^{18} \mathrm{O}$ and its relationship with Italian orography. They elaborated a map of the spatial distribution of the quantity of $\delta^{18} \mathrm{O}$ in precipitation. In addition, they demonstrated how $\delta^{18} \mathrm{O}$ distribution over the Alps clearly depends on latitude and altitude, whereas over the Apennines, it is more affected by altitude. Moreover, the isotopic compositions on the western side of Italy are generally higher than those on the eastern side, given the same elevation and latitude. The LMWLs of northern, southern and central Italy and Sicily were thus reformulated (Table 3). 
Table 3. LMWLs formulated by [30].

\begin{tabular}{cc}
\hline Area & Equation \\
\hline Italy & $\delta \mathrm{D}=8.32( \pm 0.13) \delta^{18} \mathrm{O}+15.37( \pm 1.01)\left(\mathrm{N}=220 ; \mathrm{R}^{2}=0.95\right)$. \\
\hline Northern Italy & $\delta \mathrm{D}=8.04( \pm 0.13) \delta^{18} \mathrm{O}+11.47( \pm 1.18)$ \\
\hline Central Italy & $\delta \mathrm{D}=7.46( \pm 0.32) \delta^{18} \mathrm{O}+8.29( \pm 2.33)$ \\
\hline Southern Italy & $\delta \mathrm{D}=6.94( \pm 0.45) \delta^{18} \mathrm{O}+6.41( \pm 2.65)$ \\
\hline
\end{tabular}

Isotopic studies on the Aosta Valley area are few, fragmented and outdated. In [32,33], the authors obtained the equation for the regional local meteoric water line. The local meteoric water line, formulated in 1995, was calibrated by using isotopic data for surface water only, whereas the line proposed in 2002 was calibrated using groundwater data only (Table 4).

Table 4. LMWLs formulated by $[32,33]$.

\begin{tabular}{cc}
\hline Area & Equation \\
\hline Western Aosta Valley (1995) & $\delta \mathrm{D}=7.92 \delta^{18} \mathrm{O}+8.65$ \\
\hline Aosta Valley (2002) & $\delta \mathrm{D}=8.0 \delta^{18} \mathrm{O}+13$ \\
\hline
\end{tabular}

Vuillermoz [34] analysed surface water and groundwater in the northernmost part of the study area (Ferret Valley). The author obtained a $\delta^{18} \mathrm{O}$ value of $-16.51 \%$ for surface water (of the Dora di Ferret stream on 7 May 1993) and data for the Fréboudze spring (in Courmayeur town); these are listed in Table 5.

Table 5. Groundwater isotopic data of Fréboudze spring as determined by [34].

\begin{tabular}{cccc}
\hline Date & $\boldsymbol{\delta}^{\mathbf{1 8}} \mathbf{O}[\% \mathbf{~}]$ & Date & $\boldsymbol{\delta}^{\mathbf{1 8}} \mathbf{O}[\% \mathbf{~}]$ \\
\hline $08 / 92$ & -14.79 & $30 / 01 / 93$ & -14.29 \\
$09 / 92$ & -14.45 & $07 / 03 / 93$ & -13.58 \\
$10 / 92$ & -14.45 & $28 / 03 / 93$ & -14.15 \\
$11 / 92$ & -14.67 & $05 / 93$ & -13.77 \\
$12 / 92$ & -14.65 & $06 / 93$ & -14.34 \\
$05 / 01 / 93$ & -14.43 & $07 / 93$ & -13.58 \\
\hline
\end{tabular}

Alemani et al. [35] studied the isotopes of the Dora di La Thuile stream, located in the middle of the study area. They obtained a $\delta^{18} \mathrm{O}$ value of $-13.67 \%$ and a $\delta^{2} \mathrm{H}$ value of $-99.49 \%$.

Other historical and fragmentary isotopic data for the surface water and groundwater in sectors close to the study area (Val Veny) are reported in [36,37]. Alemani et al. [35] reported isotopic data for the hydrothermal aquifer of Pré-Saint-Didier, which is located in the central part of the study area.

\section{Materials and Methods}

This study was conducted by performing five monthly sampling campaigns from August to December of 2019. More specifically, 170 water samples were collected (64 surface water samples from 7 streams, 69 groundwater samples from 15 springs, 34 rain samples from 10 sites and 3 snow samples; Figure 2, Table 6). 


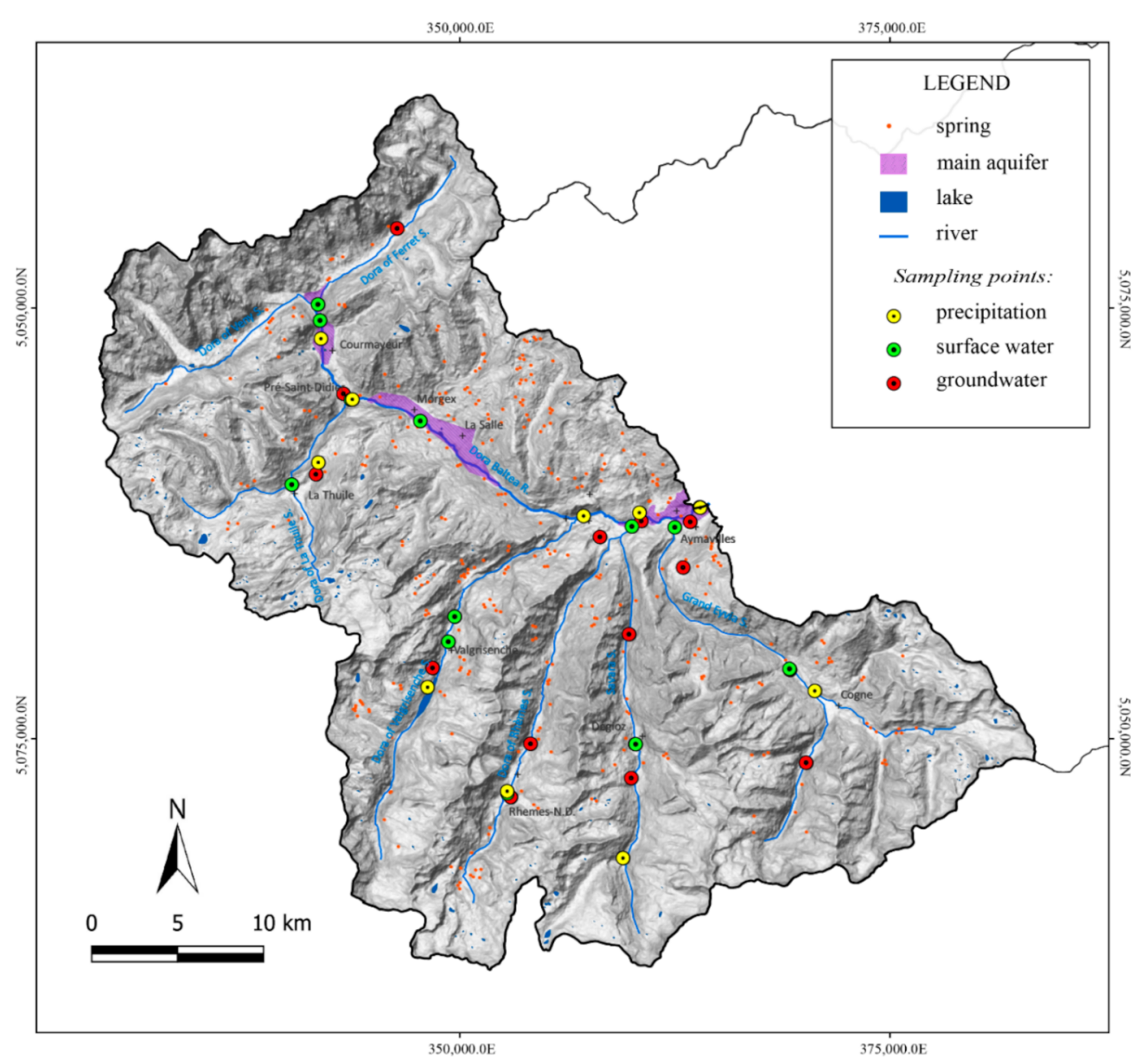

Figure 2. Map of the sampling points.

Surface water collection was performed by lowering a tank from selected bridges to collect a sample along the river midline, making samples as representative as possible.

The groundwater sample collection was performed by filling the sample bottles directly from the springs.

The collection of rain samples required the previous installation of rain collectors. For each rainwater sampling site, a water collector for chemical analyses and another one for isotopic analyses, manufactured using International Atomic Energy Agency (IAEA) guidelines [38], were installed. In the water collector for isotopic analyses, a film of paraffin oil was added to significantly reduce evaporation, which would distort the isotopic results (Figure 3). In the November campaign, three snow samples were collected by manually filling sampling bottles with snow and subsequently letting it melt.

Table 6. Details of the sampling campaigns. $\mathrm{P}=$ precipitation, $\mathrm{S}=$ surface water, $\mathrm{G}=$ groundwater.

\begin{tabular}{|c|c|c|c|c|c|c|c|c|c|}
\hline \multirow{2}{*}{ Sampling Campaign } & \multicolumn{3}{|c|}{ Number of Collected Samples } & \multicolumn{3}{|c|}{$\begin{array}{c}\text { Number of Performed } \\
\text { Chemical Analyses }\end{array}$} & \multicolumn{3}{|c|}{$\begin{array}{c}\text { Number of Performed } \\
\text { Isotopic Analyses }\end{array}$} \\
\hline & $\mathbf{P}$ & $\mathrm{S}$ & G & $\mathbf{P}$ & $\mathrm{S}$ & $\mathrm{G}$ & $\mathbf{P}$ & $\mathbf{S}$ & G \\
\hline August & 7 & 13 & 15 & 7 & 13 & 15 & 7 & 13 & 15 \\
\hline September & 7 & 13 & 14 & 0 & 2 & 0 & 3 & 2 & 2 \\
\hline October & 10 & 13 & 15 & 4 & 2 & 4 & 5 & 2 & 0 \\
\hline November & 8 (+3 snow) & 12 & 12 & $3(+2)$ & 12 & 12 & $4(+3)$ & 2 & 6 \\
\hline December & 2 & 13 & 13 & 0 & 0 & 0 & 0 & 0 & 0 \\
\hline Subtotal & $34(+3$ snow $)$ & 64 & 69 & $14(+2)$ & 29 & 32 & $19(+3)$ & 19 & 23 \\
\hline Total & \multicolumn{3}{|c|}{$167(+3$ snow $)$} & \multicolumn{3}{|c|}{$75(+2$ snow $)$} & \multicolumn{3}{|c|}{$61(+3$ snow $)$} \\
\hline
\end{tabular}




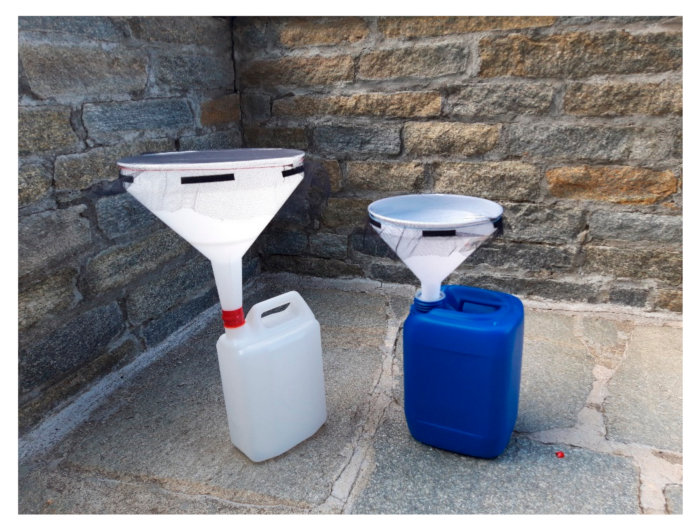

Figure 3. Rain sample collectors. On the left is the collector for chemical analyses; on the right is the collector for isotopic analyses, to which a film of paraffin was added.

From each surface water (i.e., streams) and groundwater (i.e., springs) sampling point, two water samples were collected, as follows:

- One aliquot was collected inside a polyethylene cylindrical bottle with a capacity of $250 \mathrm{~mL}$ and a wide neck, screw cap, and sealing disc.One aliquot (the control sample) was collected inside a polyethylene terephthalate (PET) bottle with a capacity of $500 \mathrm{~mL}$.

From the precipitation sampling points, four samples were collected, where quantitatively available, as follows:

- One aliquot was collected inside a polyethylene cylindrical bottle with a capacity of $250 \mathrm{~mL}$ and a wide neck, screw cap, and sealing disc, and one aliquot (the control sample) was collected inside a PET bottle with a capacity of $500 \mathrm{~mL}$; both were collected from precipitation samples taken from the rain gauges without the paraffin oil.

- One aliquot was collected inside a polyethylene cylindrical bottle with a capacity of $250 \mathrm{~mL}$ and a wide neck, screw cap, and sealing disc, and one aliquot (the control sample) was collected inside a PET bottle with a capacity of $500 \mathrm{~mL}$; both were collected from a precipitation sample taken from the rain collector with paraffin oil.

Field measurements of temperature and electrical conductivity were performed in situ during the sampling campaign by using a conductivity meter "WTW 3310 ", and pH was determined with a $\mathrm{pH}$ meter "HI 9125".

Collected water samples were then transported inside portable refrigerators to maintain a constant temperature and to prevent light exposure. They were stored inside a refrigerator at a constant temperature of $4{ }^{\circ} \mathrm{C}$.

The temperature, $\mathrm{pH}$ and electrical conductivity $(\mathrm{EC})$ were measured in situ for all of the samples.

Among the 170 water samples, 77 samples were selected and analysed (Table 6) at the Hydrology Laboratory of the Earth Science Department (University of Torino). Almost all the water samples for the August and November sampling campaigns were analysed. Moreover, all the samples from the Dora Baltea River were analysed to investigate the temporal variation of water quality along the valley. The samples that were found to be abnormal (e.g., samples with high turbidity or from tampered rain collectors) were excluded from the study. Finally, the remaining water samples analysed were distributed as evenly as possible across the territory.

The analysed parameter was total alkalinity (the sum of $\mathrm{CO}_{3}^{=}+\mathrm{HCO}_{3}^{-}$using the acid-base titration method). The main anions and cations $\left(\mathrm{NO}_{2}^{-}, \mathrm{F}^{-}, \mathrm{SO}_{4}^{-}, \mathrm{NO}_{3}^{-}, \mathrm{Cl}^{-}\right.$, $\mathrm{Ca}^{2+}, \mathrm{Mg}^{2+}, \mathrm{Na}^{+}, \mathrm{K}^{+}$) were measured using Compact IC Metrohm Ion chromatography.

The ions in solution were determined by acid-base titration with the Warder method using the "665 Dosimat" titrator and the "883 Basic IC plus Metrohm" ion chromatograph; isotopic analyses were performed with a CRDS (Cavity Ringdown Spectroscopy) LWIA24d Los Gatos. 
Finally, 64 samples chosen as representative samples were analysed at the Isotopic Geochemistry Laboratory of the University of Ferrara with the aim of defining the water stable isotope rate (by the use of laser spectroscopy CRDS, Table 6). More specifically, stable oxygen and hydrogen isotopes were analysed using spectroscopy techniques.

Chemical data were graphically evaluated using a Piper ternary diagram and a Schoeller semi-log plot; isotopic data were evaluated using biplots.

Isotopic concentrations are reported using the delta ( $\delta$ ) notation, which is the deviation in parts per thousand from the standard used at the laboratory. Such notation can be obtained with the following equations:

$$
\begin{aligned}
\delta^{18} \mathrm{O} \% \mathrm{o} & =\left(\frac{\left(\frac{18 \mathrm{O}}{1{ }^{16} \mathrm{O}}\right)_{\text {sample }}}{\left(\frac{18 \mathrm{O}}{{ }^{16} \mathrm{O}}\right)_{\text {standard }}}-1\right) \cdot 1000 \\
\delta \mathrm{D} \% \mathrm{o} & =\left(\frac{\left(\frac{D}{{ }^{1} H}\right)_{\text {sample }}}{\left(\frac{D}{{ }^{1} H}\right)_{\text {standard }}}-1\right) \cdot 1000
\end{aligned}
$$

In addition, deuterium excess was calculated. This is a parameter related to the water kinetic fractionation and is conditioned by physical system conditions, mainly relative humidity and air temperature, both at the evaporation and precipitation formation areas, and the evaporating surface temperature, wind speed and re-evaporation phenomena occurring in the air column at the moment of precipitation formation [39]. Deuterium excess, depending on both the primary source and the transport conditions of wet air masses, is considered a good tracer to determine the precipitation origin.

Deuterium excess was calculated using the Dansgaard equation [40], as follows:

$$
d \%=\delta \mathrm{D}-8 \delta^{18} \mathrm{O}
$$

Furthermore, the vertical isotope gradient of the western Aosta Valley was evaluated by relating the isotope values of $\delta^{18} \mathrm{O}$ of precipitation to the altitude; the vertical isotope gradient is the slope of the line obtained, expressed in \%.

\section{Results and Discussion}

\subsection{Chemical Analyses}

All the sampled waters, according to the Mouren classification [41], were classified as cold waters; surface water temperatures did not exceed $20^{\circ} \mathrm{C}$, with minimum values of approximately $0{ }^{\circ} \mathrm{C}$ recorded in November and December of 2019 and maximum values of $14.3^{\circ} \mathrm{C}$ recorded in August 2019 (Figure 4, Table 7). As expected, the surface water temperature gradually decreased in the cold season and due to the sampling altitude. A similar result was observed in the Piedmont alluvial plain, which is close to the Aosta Valley [42].

\begin{tabular}{|c|c|c|c|c|c|c|c|c|c|c|c|c|}
\hline & \multicolumn{4}{|c|}{ Temperature $\left({ }^{\circ} \mathrm{C}\right)$} & \multicolumn{4}{|c|}{ Electrical Conductivity $(\mu \mathrm{S} / \mathrm{cm})$} & \multicolumn{4}{|c|}{$\mathrm{pH}$} \\
\hline & $\max$ & $\min$ & avg & $\begin{array}{l}\text { std. } \\
\text { dev. }\end{array}$ & $\max$ & $\min$ & avg & $\begin{array}{l}\text { std. } \\
\text { dev. }\end{array}$ & $\max$ & $\min$ & avg & $\begin{array}{l}\text { std. } \\
\text { dev. }\end{array}$ \\
\hline PRECIPITATION & - & - & - & - & 30.3 & 3.4 & 13.8 & 7.7 & 8.6 & 6.5 & 7.3 & 0.5 \\
\hline SURFACE WATER & 12.9 & 0.1 & 6.8 & 3.5 & 519.0 & 46.4 & 182.1 & 104.1 & 8.6 & 7.2 & 7.9 & 0.3 \\
\hline GROUNDWATER & 14.3 & 1.8 & 7.38 & 2.9 & 704.0 & 61.0 & 298.2 & 216.0 & 8.3 & 7.2 & 7.7 & 0.3 \\
\hline
\end{tabular}

Table 7. Maximum, minimum and average values and standard deviations of water temperature, electrical conductivity and $\mathrm{pH}$ from field measurements. 

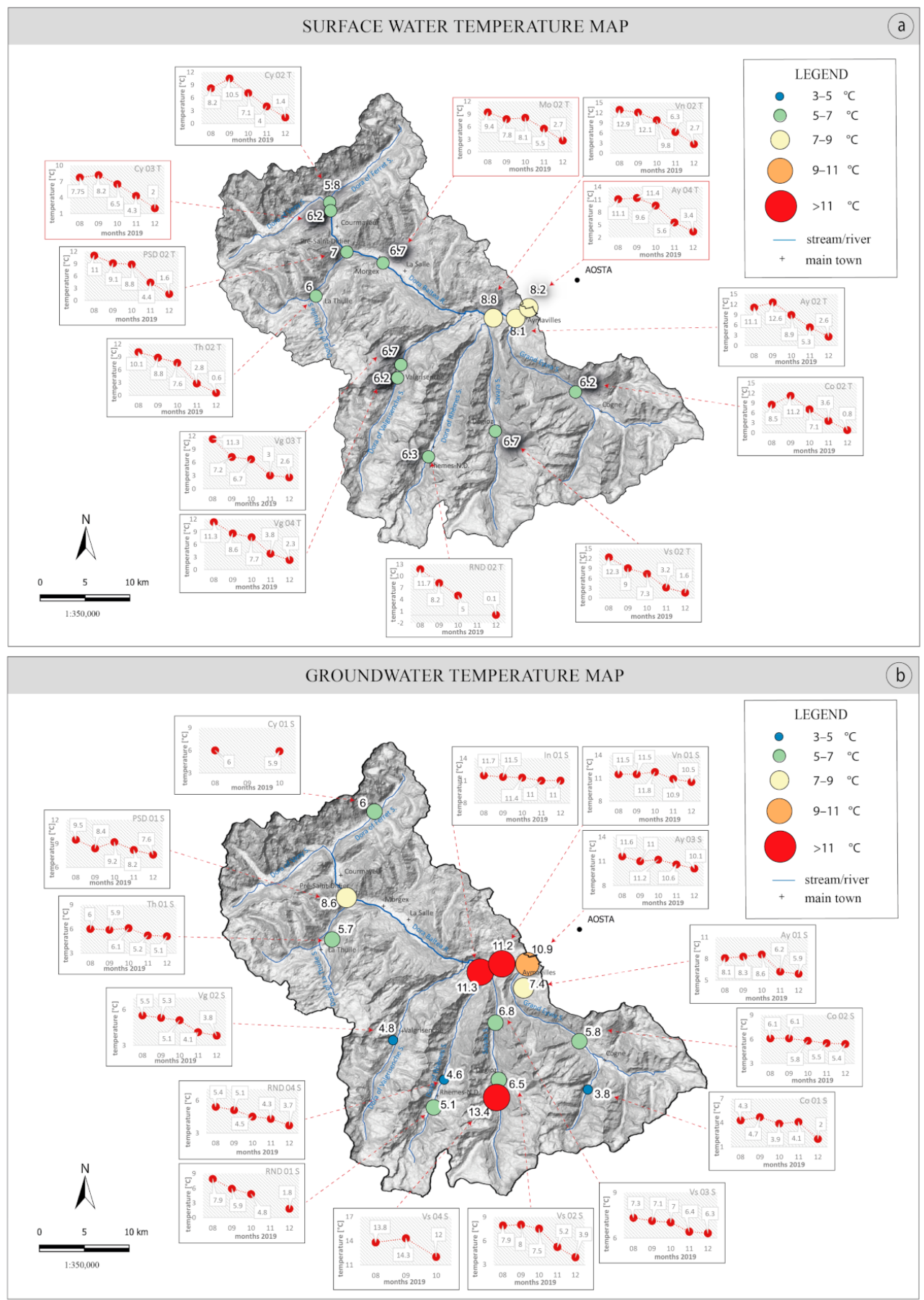

Figure 4. Temperature maps of (a) surface water and (b) groundwater.

The groundwater temperatures ranged between $1.8^{\circ} \mathrm{C}$ in December 2019 and $11.8^{\circ} \mathrm{C}$ in the autumn. Moreover, groundwater temperatures showed a smaller range of variation during the year as well as spatially. One groundwater sampling point (the spring of "EauxRousses" (red waters) in Valsavarenche) was excluded from the minimum, maximum and average groundwater data evaluation (Table 7) because of its particular mineralogical properties $[43,44]$, which could cause an overestimation of the evaluated parameters.

The electrical conductivity (EC) in surface waters ranged from $46.4 \mu \mathrm{S} / \mathrm{cm}$ to $519 \mu \mathrm{S} / \mathrm{cm}$. Maxima values were recorded along the main valley floor. The EC in groundwater varied between $61.0 \mu \mathrm{S} / \mathrm{cm}$ and $704 \mu \mathrm{S} / \mathrm{cm}$. The EC showed low values in the precipitation (from values close to zero to a maximum of $30.3 \mu \mathrm{S} / \mathrm{cm}$, Figure 5, Table 7). The EC increased with 
the approaching cold season in both surface water and groundwater when snow replaced rainfall, which was responsible for solute dilution in water, especially in the highest areas of hydrological basins.

Finally, EC variations in the precipitation overlapped accurately with the spatial variations in dust aerosol pollution, which were analysed and mapped in accordance with [45] (see Figure 6).

In the entire area, the groundwater $\mathrm{pH}$ was close to neutral and was generally constant and independent in relation to the altitude and the season (Figure 7, Table 7). In some cases, $\mathrm{pH}$ tended to be slightly alkaline in surface water and groundwater samples (the maximum recorded value was 8.3) and slightly acidic in some precipitation samples (the minimum recorded value was 6.5). Slightly alkaline values were due to aquifer mineralogy; more alkaline $\mathrm{pH}$ values were generally recorded where water came into contact predominantly with carbonate rocks. In this case, a greater abundance of $\mathrm{HCO}_{3}^{-}$ions in solution was also observed (Table 8). Slightly acidic values in precipitation were due to soluble acidifying compounds (air pollution).

The analysed anions and cations in surface water and groundwater are reported in Table 8 and Figures 8 and 9. The main ions in solution are $\mathrm{HCO}_{3}^{-}, \mathrm{Ca}^{++}$and $\mathrm{SO}_{4}^{=} ; \mathrm{Na}^{+}$, $\mathrm{Mg}^{++}$, and $\mathrm{K}^{+}$show lower concentrations, and $\mathrm{Cl}^{-}, \mathrm{F}^{-}, \mathrm{NO}_{2}^{-}$and $\mathrm{NH}_{4}^{+}$generally have very low concentrations.

In groundwater, we observed a general constancy of the measured parameters in relation to both the season and the altitude of springs. This was mainly because significant water mixing occurred in the aquifers.

In contrast, surface water (especially in the Dora Baltea River) showed a higher variability related to both the season and the altitude of the sampling location. The Dora Baltea River receives contributions from both lateral streams and groundwater. In addition, the Dora Baltea River flows into the main valley floor, where the main urban centres, which are potential sources of pollution, are located.

According to the Piper diagram (Figure 9), the groundwater and the surface water were calcium bicarbonate waters. However, in some surface water and groundwater, especially in the cold season, some samples showed a calcium sulfate facies. This phenomenon was due to the blocking of surface drainage during the cold months. In the winter, streams drained almost exclusively spring waters that were rich in sulfate because of their location in hydrogeologic basins, which were composed of important gypsum layers, evaporitic rocks and dolomites and are also responsible for local karst formations.

The groundwater and surface water chemistry was directly dependent on the surrounding lithology. The predominance of $\mathrm{Ca}-\mathrm{HCO}_{3}$ in the water complied with reservoir lithology in the study area, which was characterized by prevailing heterogeneous quaternary deposits, silicate-rich metamorphic rocks, ophiolites, and importantly, mica shists and several carbonate layers.

For example, the maximum concentrations of $\mathrm{Ca}^{++}$were in springs located in calcschists, glacial deposits or unsorted deposits that were slightly downstream of carbonate or evaporitic layers (marbles, limestones and dolomite). The maximum concentration of $\mathrm{SO}_{4}^{\bar{y}}$ was in the Dora di La Thuile stream, which drained a water basin that was composed, upstream, of important gypsum layers, dolomite and evaporitic rocks.

Human activity also affects surface water chemistry through, for example, sewage system waste, street cleaning and de-icing salt on streets during the winter. As a consequence, at some sampling points along the main valley floor and near the main towns, higher concentrations of $\mathrm{SO}_{4}^{=}, F^{-}$and/or $\mathrm{Cl}^{-}$were found, although none of these exceeded the limits specified by national law (D.Lgs. 152/06 and subsequent amendments).

In precipitation, the solute concentrations were often close to the limits of detection. The $\mathrm{NO}_{3}^{-}$concentrations varied from a few dozen to hundreds of $\mu \mathrm{g} / \mathrm{L}$. Locally, some seasonal variations in ion levels in solution were observed, e.g., an increase in $\mathrm{SO}_{4}^{=}$and a decrease in $\mathrm{HCO}_{3}^{-}$during the cold season. 


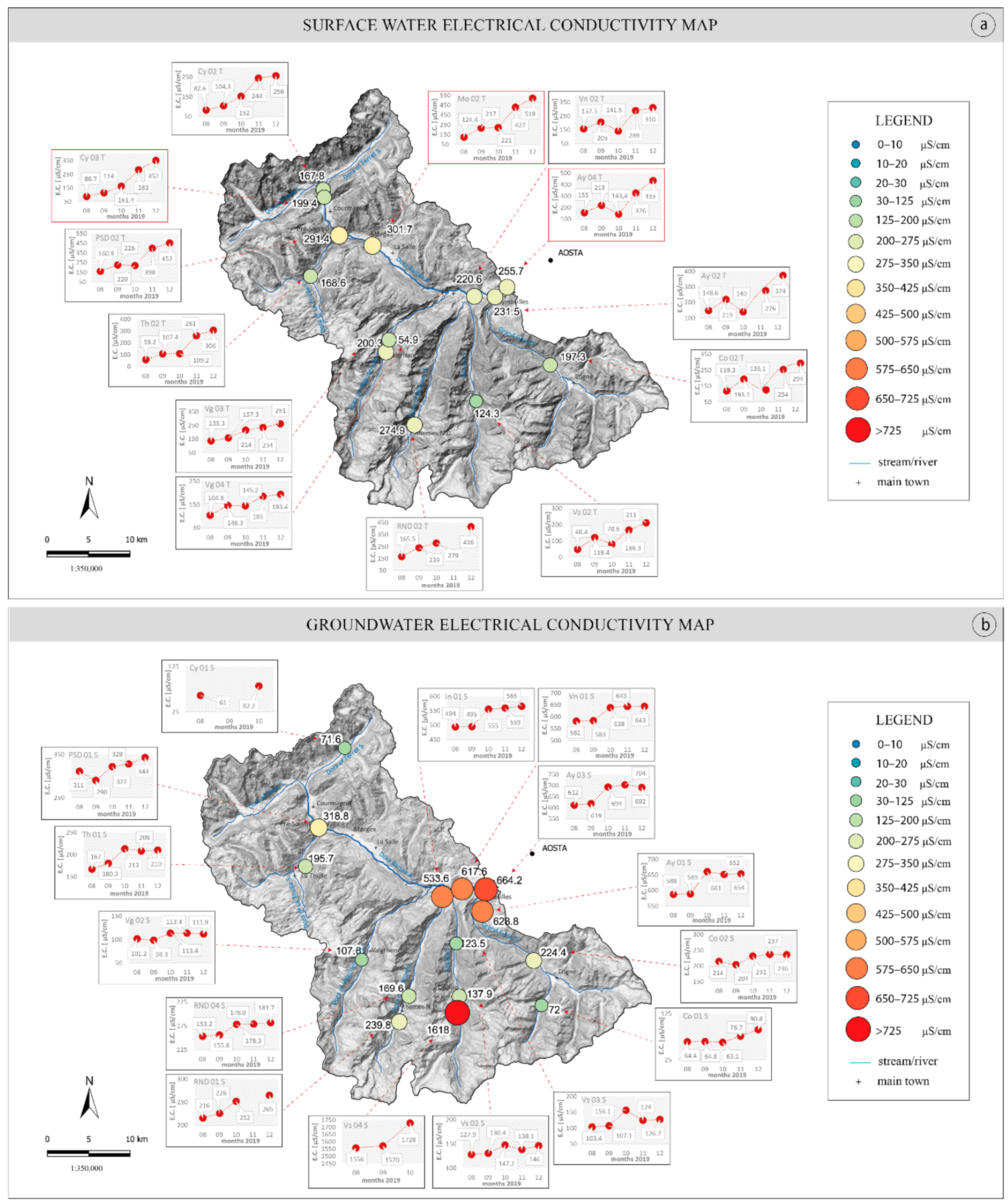

Figure 5. Electrical conductivity (EC) maps of (a) surface water and (b) groundwater. 

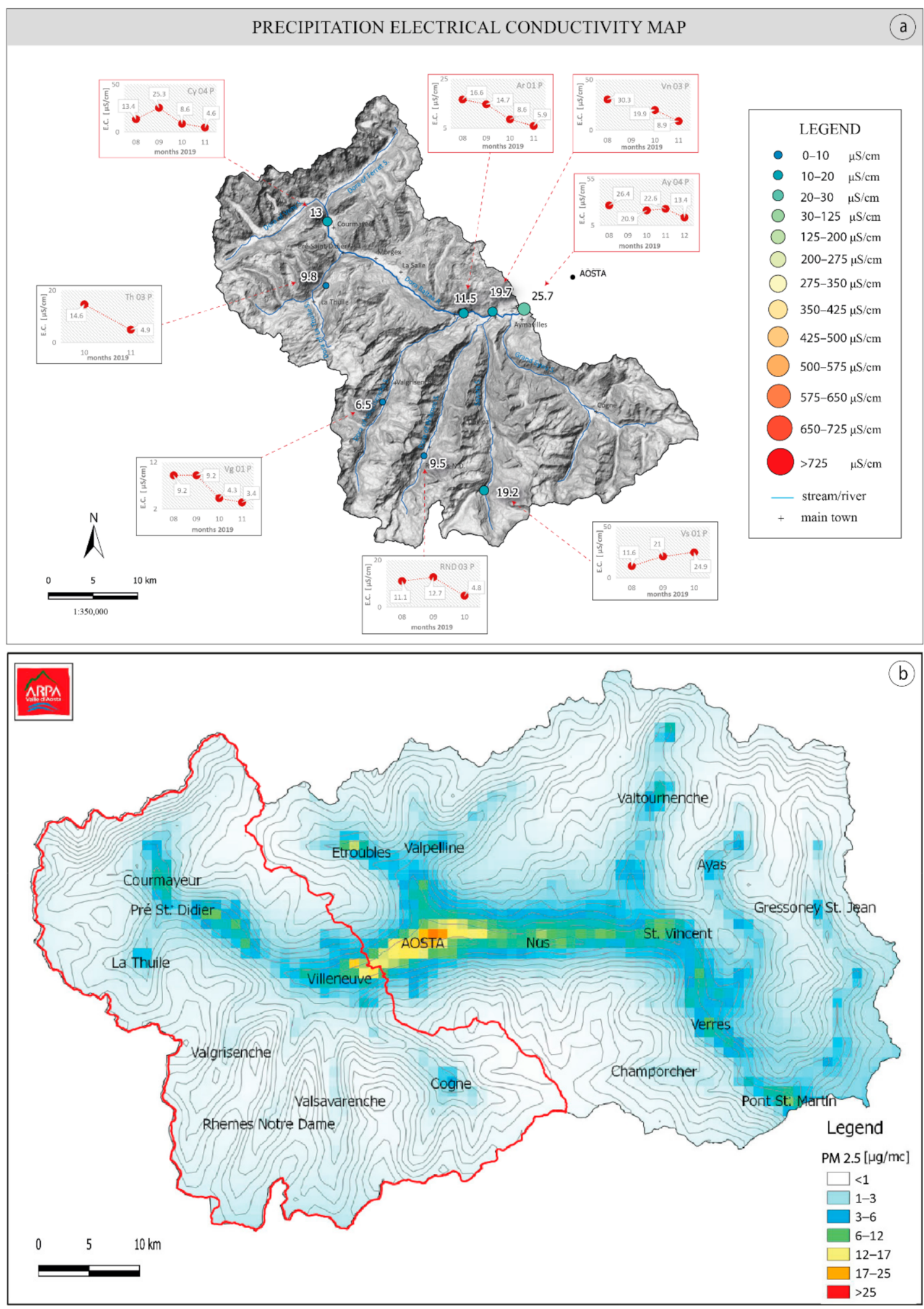

Figure 6. Comparison between (a) EC precipitation map and (b) Particulate matter (PM) 2.5 map ([45] modified). 

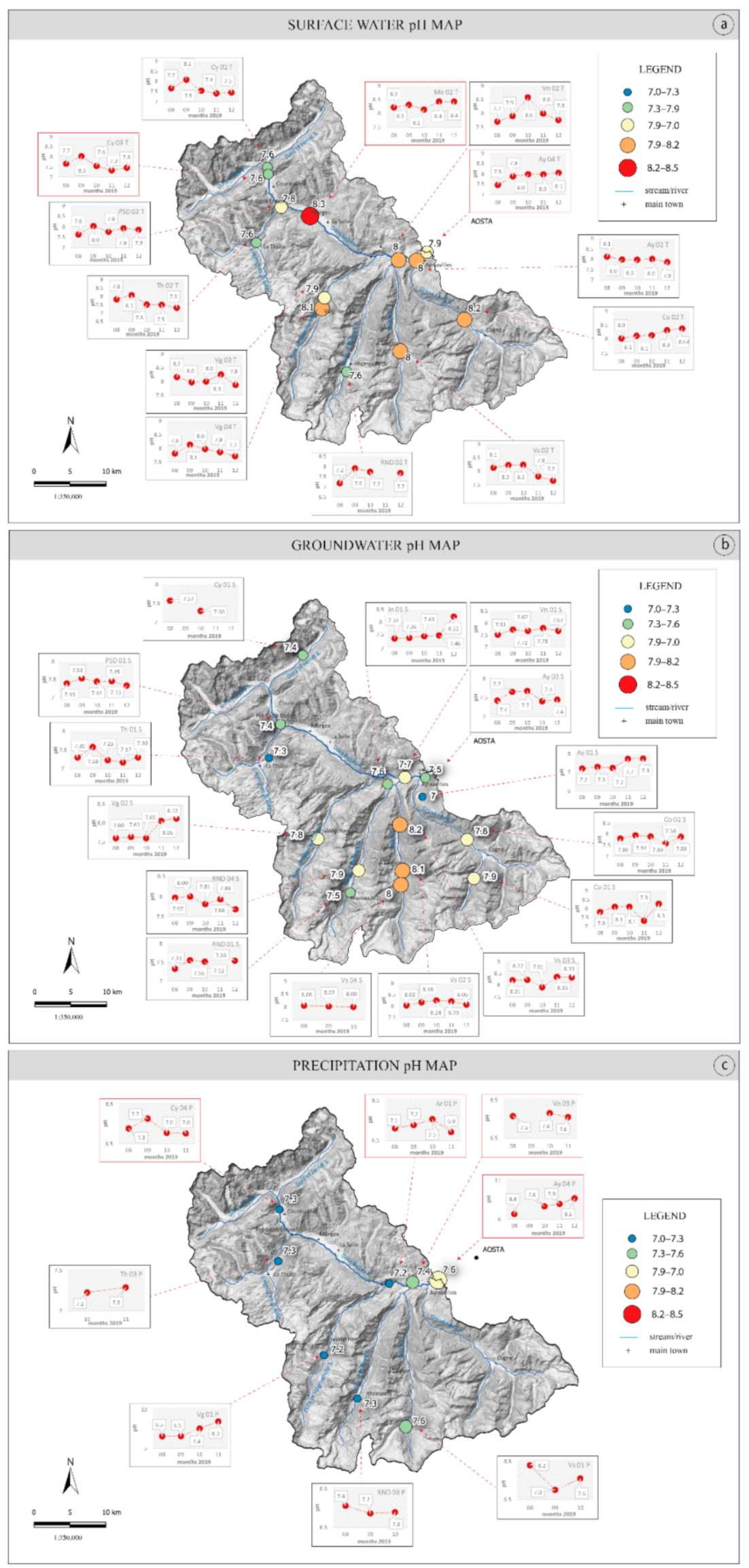

Figure 7. The $\mathrm{pH}$ maps of (a) surface water, (b) groundwater and (c) precipitation. 


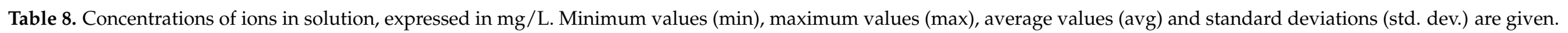

\begin{tabular}{|c|c|c|c|c|c|c|c|c|c|c|c|c|}
\hline & \multicolumn{4}{|c|}{$\mathrm{HCO}_{3}{ }^{-}$} & \multicolumn{4}{|c|}{$\mathbf{F}^{-}$} & \multicolumn{4}{|c|}{$\mathrm{Cl}^{-}$} \\
\hline & $\min$ & $\max$ & avg & std. dev & $\min$ & $\max$ & avg & std. dev. & $\min$ & $\max$ & avg & std. dev. \\
\hline Rain & 2.6 & 16.1 & 7.4 & 4,1 & 0.02 & 0.03 & 0.2 & 0.00 & 0.06 & 1.04 & 0.24 & 0.24 \\
\hline Surface water & 17.0 & 116.8 & 67.2 & 26.1 & 0 & 0.15 & 0.06 & 0.06 & 0.06 & 7.2 & 1.93 & 1.8 \\
\hline \multirow[t]{3}{*}{ Groundwater } & 17.4 & 325 & 130.3 & 96.1 & 0 & 0.3 & 0.04 & 0.07 & 0 & 29.1 & 3.8 & 7.3 \\
\hline & \multicolumn{4}{|c|}{$\mathrm{NO}_{3}{ }^{-}$} & \multicolumn{4}{|c|}{$\mathrm{NO}_{2}^{-}$} & \multicolumn{4}{|c|}{$\mathrm{SO}_{4}=$} \\
\hline & $\min$ & $\max$ & avg & std. dev. & $\min$ & $\max$ & avg & std. dev. & $\min$ & $\max$ & avg & std. dev. \\
\hline Rain & 0.14 & 2.4 & 1.02 & 0.70 & 0 & 0.46 & 0.10 & 0.13 & 0.23 & 1.18 & 0.64 & 0.3 \\
\hline \multirow[t]{2}{*}{ Groundwater } & 0.34 & 10.9 & 2.07 & 2.85 & 0 & 0.09 & 0.01 & 0.02 & 1.3 & 89.4 & 30.4 & 27.8 \\
\hline & \multicolumn{4}{|c|}{$\mathrm{Ca}^{++}$} & \multicolumn{4}{|c|}{$\mathrm{K}^{+}$} & \multicolumn{4}{|c|}{$\mathrm{Mg}^{++}$} \\
\hline & $\min$ & $\max$ & avg & std. dev. & $\min$ & $\max$ & avg & std. dev. & $\min$ & $\max$ & avg & std. dev. \\
\hline Rain & 0.46 & 3.8 & 1.75 & 1.23 & 0.03 & 1.2 & 0.22 & 0.3 & 0 & 0.2 & 0.09 & 0.06 \\
\hline Surface water & 9.2 & 64.9 & 29.6 & 14.0 & 0 & 1.9 & 1.04 & 0.48 & 0.6 & 7.9 & 3.56 & 2.14 \\
\hline \multirow[t]{2}{*}{ Groundwater } & 9.0 & 77.5 & 36.04 & 20.9 & 0.4 & 5.4 & 1.6 & 1.1 & 0.5 & 39.0 & 9.75 & 11.3 \\
\hline & \multicolumn{4}{|c|}{$\mathrm{Na}^{+}$} & \multicolumn{4}{|c|}{$\mathrm{NH}_{4}{ }^{+}$} & & & & \\
\hline Rain & 0.1 & 1.2 & 0.27 & 0.28 & 0.08 & 3.0 & 0.62 & 0.74 & & & & \\
\hline Surface water & 0.25 & 6.86 & 2.13 & 1.6 & 0 & 0.6 & 0.15 & 0.14 & & & & \\
\hline Groundwater & 0.33 & 24.2 & 3.65 & 5.9 & 0 & 1.0 & 0.17 & 0.23 & & & & \\
\hline
\end{tabular}




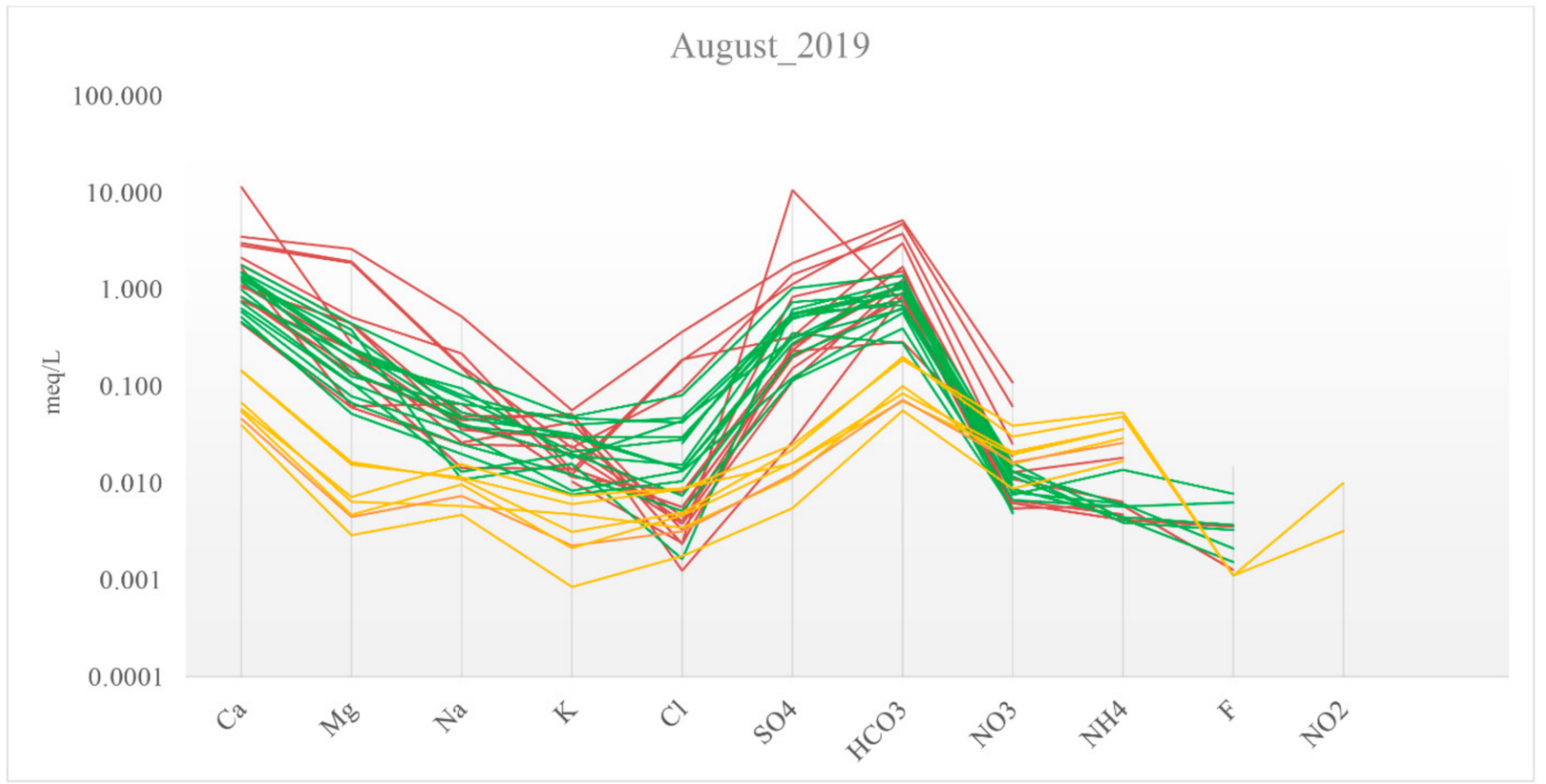

Figure 8. Schoeller diagram of waters sampled in August 2019. Green lines represent surface water, red lines represent groundwater and orange lines represent precipitation.

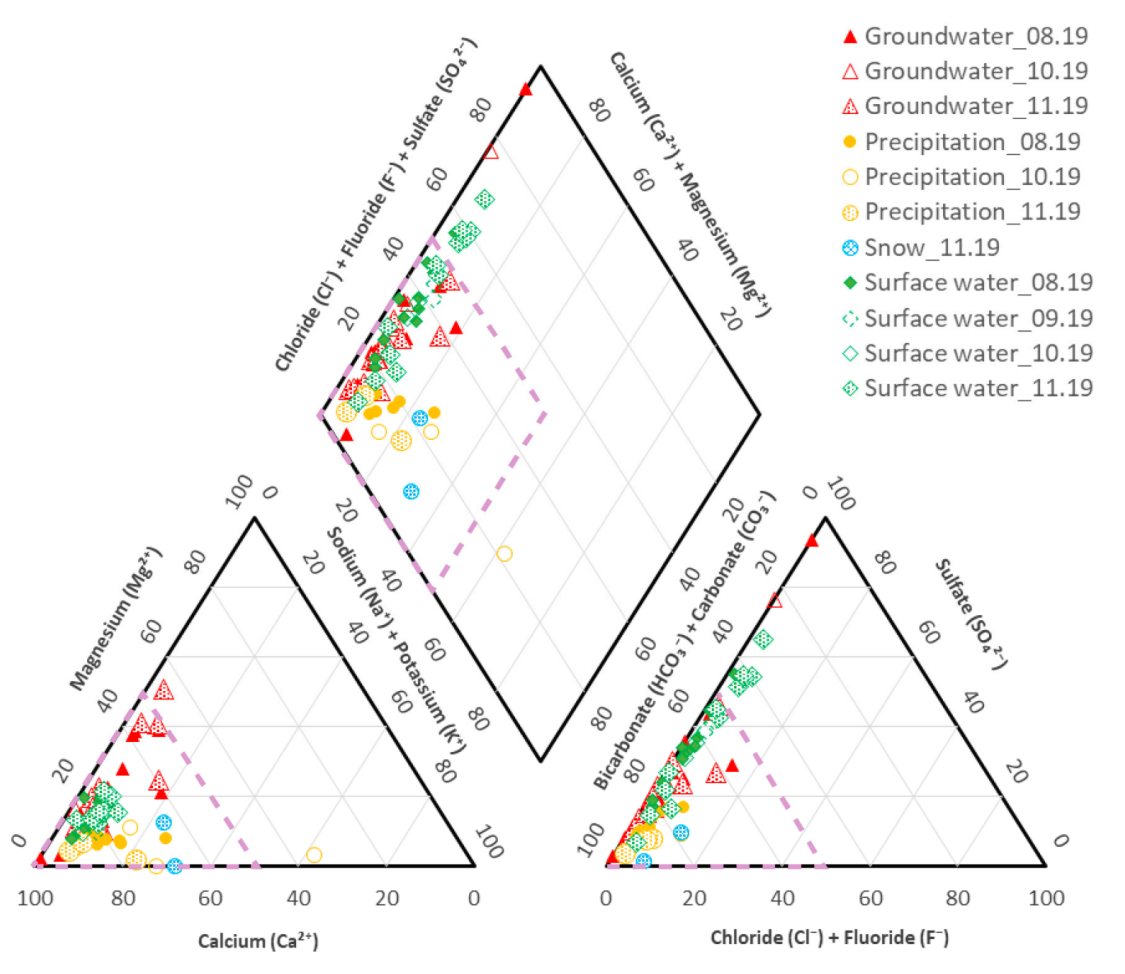

Figure 9. Piper diagram. The purple dotted line highlights the $\mathrm{HCO}_{3}-\mathrm{Ca}$ facies.

In general, precipitation chemistry is directly related to aerosol composition at the time of the formation of precipitation. The spatial distribution of ionic compounds in precipitation reflects the atmospheric distribution of aerosol compounds with the same 
chemistry in a very similar way. A LiDAR analysis of aerosols conducted by the Aosta Valley ARPA also demonstrated that the abundance of $\mathrm{HCO}_{3}^{-}$in solution in precipitation was due to cloud formation above an atmospheric layer characterized by the presence of carbonate sandy dust of the Sahara Desert. This dust was later transported to the ground by rain (and other kinds of precipitation). In contrast, the presence of other ionic compounds in solution at lower concentrations was assumed to be due to the presence of thin particulates with similar chemical compositions in lower atmospheric strata, which were mostly from the Po Plain, a well-known polluting hotspot $[46,47]$.

Finally, it can be asserted that there were no anomalous situations for the chemicalphysical surveyed parameters. Only local exceptions were found. Examples include a surface water sampling point in Courmayeur, next to an open-air salt storage; the EauxRousses sampling point in Valsavaranche, characteristic of a Fe-carbonatic spring; the precipitation collected in Aymavilles (whose sampling point was near to an industrial area), where rain sometimes became slightly acidic due to air pollution. Therefore, according to Italian law (D.Lgs. 152/06 and 30/09), the studied water quality status could be considered "good".

\subsection{Isotopic Analyses}

Isotopic analyses of precipitation (Table 9, Figure 10) highlighted that in rain, the average value of $\delta^{18} \mathrm{O}$ was equal to $-7.7 \%$ (std. dev. 4.4); it had a minimum value (recorded in November 2019) equal to $-15.3 \%$, and a maximum value (recorded in August 2019) equal to $-2.5 \%$. Monthly variations were significant. In August, the average value was $-3.6 \%$ (std. dev. 0.98); in September, it was $-5.3 \%$ (std. dev. 0.85); in October, it was $-9.7 \%$ (std. dev. 0.9 ); it became increasingly negative in November, equal to $-14.4 \%$ (std. dev. 1.0). Moreover, increasingly negative values were observed at increasing altitudes. Isotopic snow values collected in November 2019 were more negative; the average $\delta^{18} \mathrm{O}$ value was equal to $-21.1 \%$ (std. dev. 0.4 ).

Table 9. Maximum, minimum and standard deviation of isotopic parameters.

\begin{tabular}{|c|c|c|c|c|c|c|c|c|c|c|c|c|}
\hline & \multicolumn{4}{|c|}{$\delta^{18} \mathrm{O}[\%]$} & \multicolumn{4}{|c|}{$\delta^{2} \mathrm{H}[\% \mathrm{o}]$} & \multicolumn{4}{|c|}{ Deuterium Excess [\%o] } \\
\hline & $\max$ & $\min$ & avg & std.dev. & $\max$ & $\min$ & avg & std.dev. & $\max$ & $\min$ & avg & std.dev. \\
\hline $\begin{array}{l}\text { PRECIPITATION } \\
\text { (RAIN) }\end{array}$ & -2.5 & -15.3 & -7.7 & 4.4 & -10.5 & -106.7 & -49.3 & 32.2 & 22.3 & 1.7 & 12.7 & 5.0 \\
\hline $\begin{array}{l}\text { PRECIPITATION } \\
\text { (SNOW) }\end{array}$ & -20.8 & -21.6 & -21.1 & 0.4 & -151.1 & -156.1 & -153.2 & 2.6 & 21.7 & 10.1 & 15.9 & 5.8 \\
\hline SURFACE WATER & -10.8 & -14.4 & -13.1 & 0.8 & -71.6 & -101.9 & -91.1 & 6.8 & 19.3 & 8.8 & 13.9 & 3.0 \\
\hline GROUNDWATER & -11.9 & -15.4 & -14.2 & 0.8 & -80.5 & -108.7 & -99.5 & 6.1 & 19.4 & 9.5 & 13.8 & 2.4 \\
\hline
\end{tabular}

The average $\delta^{2} \mathrm{H}$ in rain was $-49.3 \%$ (std. dev. 32.2); the minimum recorded value was $-106.7 \%$ (November 2019), while the maximum recorded value was $-10.5 \%$ (August 2019). Monthly variations were significant: in August, the average value was $19.0 \%$ (std. dev. 5.9); in September, it was $-32.6 \%$ (std. dev. 6.0), and it became more negative in October $(-61.5 \%$, std. dev. 7.0$)$ and in November ( $-99.3 \%$, std. dev. 8.2). Moreover, increasingly negative values were observed at increasing altitudes; this phenomenon was slightly more evident at the beginning of the cold season. Isotopic values of snow sampled in November 2019 were more negative; the average value was -153.2\% (std. dev. 2.6).

The average deuterium excess in rains was $12.7 \%$ (std. dev. 5.0), the minimum was 1.7\% (August 2019), and the maximum was 22.3\%o (October 2019). Seasonal variations were remarkable: in August and September, the average values of deuterium excess were 9.6\% (std. dev. 5.1) and 9.7\% (std. dev. 0.6), respectively, and then they became $15.9 \%$ (std. dev. 4.9) and 16.0\% (std. dev. 0.7) in October and November, respectively. 


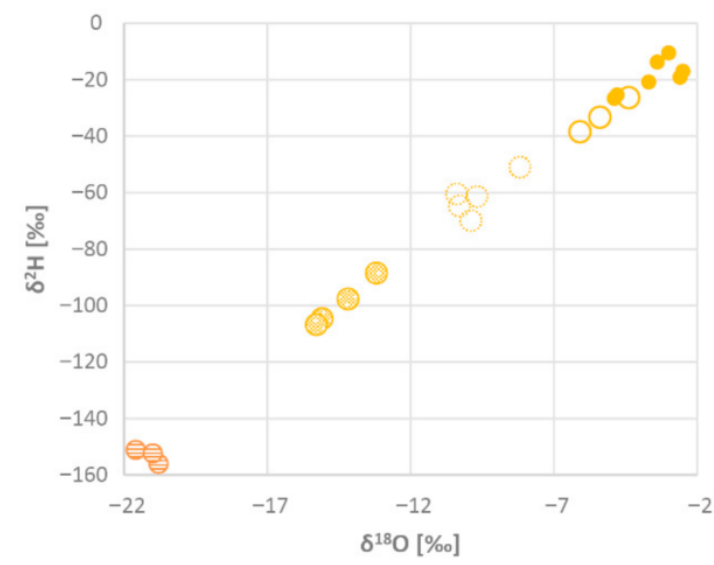

- August_2019

OSeptember_2019

October_2019

O November_2019 (rain)

๑ November_2019 (snow)

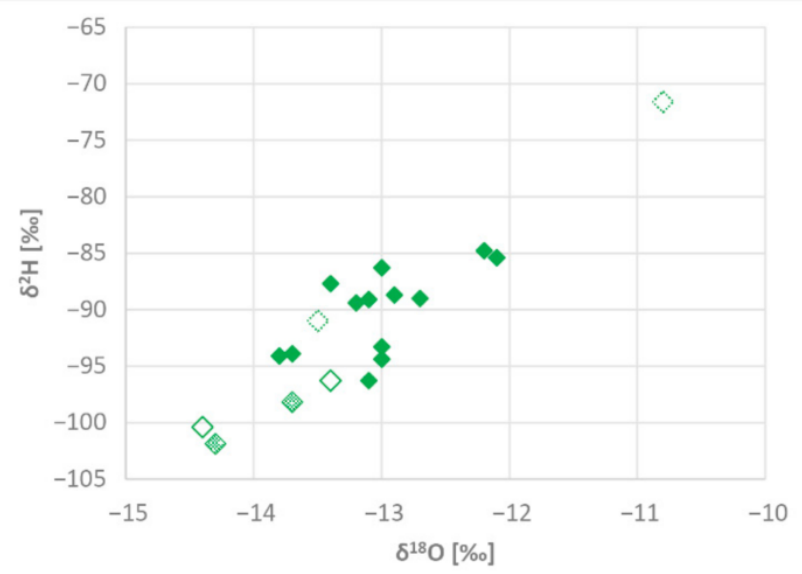

- August_2019

○ September_2019

October_2019

- November_2019

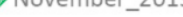

Figure 10. $\delta^{18} \mathrm{O}-\delta^{2} \mathrm{H}$ plots of (a) precipitation (yellow), (b) surface water (green) and (c) groundwater (red) samples.

The seasonal variability of isotopic parameters in precipitation is the expression of the "seasonal effect", which causes less negative values in warm months and more negative values in cold months, especially when snowfall occurs [48,49]. The isotopic distinction between summer rains and winter precipitation is due to the different temperatures at the moment of precipitation formation; precipitation with more negative isotopic values forms at lower temperatures and vice versa.

Isotopic analysis conducted on surface water (Table 9, Figure 10) found an average value of $\delta^{18} \mathrm{O}$ equal to $-13.1 \%$ (std. dev. 0.8 ); it had a minimum value (recorded in Septem- 
ber 2019) equal to $-14.4 \%$ and a maximum value (recorded in October 2019) equal to $-10.8 \%$. This parameter was found to be almost constant in time and independent spatially.

The average $\delta^{2} \mathrm{H}$ in surface water was equal to $-91.1 \%$ (std. dev. 6.8); the minimum recorded value was $-101.9 \%$ (November 2019 ), while the maximum value was $-71.6 \%$ (October 2019). $\delta^{2} \mathrm{H}$ values showed variability unrelated to both the season and the altitude of the sampling location.

The average deuterium excess in surface water was 13.9\%o (std. dev. 3.0). The recorded deuterium excess values were between a minimum of $8.8 \%$ (August 2019) and a maximum of $19.3 \%$ (August 2019). Deuterium excess values showed variability unrelated to both the season and altitude.

The isotopic analysis conducted on groundwater (Table 9, Figure 10) found an average value of $\delta^{18} \mathrm{O}$ equal to $-14.2 \%$ (std. dev. 0.8); its minimum value (recorded in August 2019) was equal to $-15.4 \%$, and its maximum value (recorded in November of 2019) was equal to $-11.9 \%$. Generally, the time and spatial parameters were constant.

The average $\delta^{2} \mathrm{H}$ in groundwater was $-99.5 \%$ (std. dev. 6.1); the minimum recorded value was $-108.7 \%$ (August 2019), while the maximum value was $-80.5 \%$ (November 2019). Generally, a constancy of the parameters was observed (only local, nearly detectable variations were registered), while no direct relation to the altitude of the sampling location was noticed.

The average deuterium excess in groundwater was $13.8 \%$ (std. dev. 2.4), and the recorded deuterium excess values were between a minimum of 9.5\% (November 2019) and a maximum of $19.4 \%$ (August 2019). Value variability was unrelated to both the season and the altitude of the sampling location.

The general constancy of isotopic values in the sampled groundwater was proof that mixing occurred in aquifers with waters of different ages (i.e., summer precipitation having isotopic values that were less negative and winter precipitation having isotopic values that were more negative) and different origins (i.e., rain as well as glacial and snow meltwaters). Aquifer recharge was due not only to rain but also to meltwater. Such conditions led to a general negativity of the mean groundwater isotopic ratio detected during all sampling months (even in the summer). Moreover, groundwater and surface water showed similar values, demonstrating that the feeding of the studied streams was mostly from groundwater. However, when significant rainfall events occurred, the isotopic composition of precipitation highly influenced the surface water isotopic composition, and it temporarily became similar to the isotopic composition of precipitation.

\subsubsection{Local Meteoric Water Line (LMWL)}

The LMWL for the study area was obtained using linear interpolation of isotopic precipitation data and plotted by correlating the $\delta^{18} \mathrm{O}$ and $\delta^{2} \mathrm{H}$ values. The LMWL is defined by the following equation:

$$
\delta^{2} \mathrm{H}=7.52 * \delta^{18} \mathrm{O}+8.57\left(\mathrm{R}^{2}=0.99\right)
$$

This equation updates the coefficients of the LMWLs proposed by Novel for the study area more than 20 years ago, which were calculated by using only the surface water isotopic data [32] or by interpolating only the groundwater isotopic data [33]. The new and updated LMWL is very similar to that formulated for northern Italy [31]. Therefore, it is possible to assume that the Aosta Valley has isotopic behaviour similar to that of neighbouring regions. Finally, all sampled water data, plotted in a $\delta^{18} \mathrm{O}-\delta^{2} \mathrm{H}$ diagram, were in close proximity to the LMWL, and the correlation coefficient, $\mathrm{R}^{2}$, was very high (0.99), which was evidence of the equation's quality (Figure 11). 


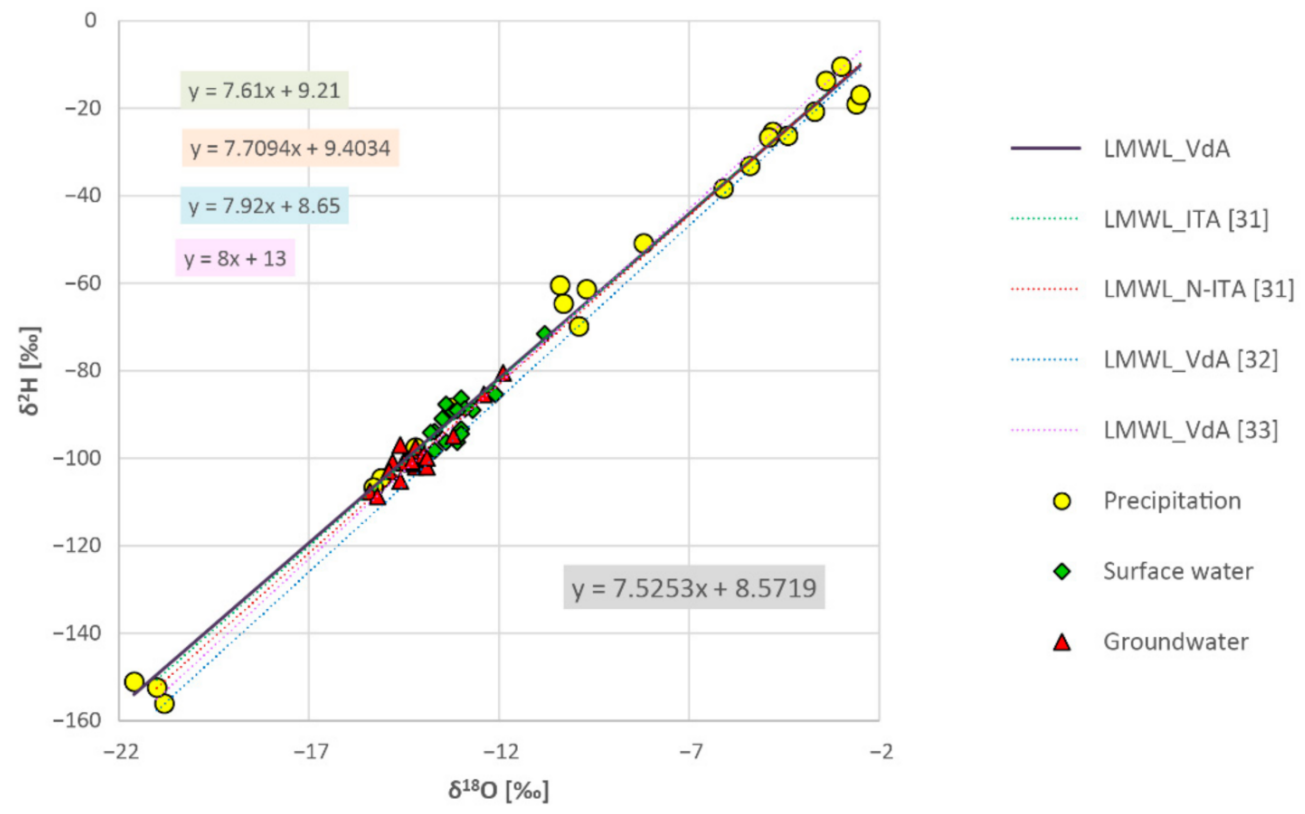

Figure 11. Comparison between the local meteoric water line (LMWL) calculated in this study for the western Aosta Valley area (black line) and LMWLs formulated by other authors (green line: LMWL for northern Italy by [31]; red line: LMWL for Italy by [31]; blue line: LMWL for the Aosta Valley by [32]; pink line: LMWL for the Aosta Valley by [33]).

\subsubsection{Vertical Isotopic Gradient}

The $\delta^{18} \mathrm{O}$ precipitation data were plotted versus the altitude of water sampling locations for each sampling campaign (Figure 12). The $\delta^{18} \mathrm{O}$ data varied widely during the year, but varied little with the altitude. More specifically, $\delta^{18} \mathrm{O}$ data showed the most positive values in August and very low values in November. Furthermore, it was observed that precipitation was gradually depleted in $\delta^{18} \mathrm{O}$ isotope as elevation increased, in accordance with the phenomenon commonly called "altitude effect".

This analysis allowed us to calculate a vertical isotopic gradient for each month from August to November, and an overall vertical isotopic gradient for the western Aosta region, using the linear regression of all the data.

The overall vertical isotopic gradient for the western Aosta Valley was equal to $-0.18 \%$ o $/ 100 \mathrm{~m}$, which is very similar to the value calculated nationwide by [31] $(-0.2 \%$ / $100 \mathrm{~m}$ ). However, this vertical isotopic gradient must be used with attention to the estimation of the mean recharge area of springs. The feeding of the aquifers in the study area was a mixture of snow and glacial meltwater as well as rainfall. Consequently, the calculated vertical isotopic gradient could lead to a significant overestimation of the spring feeding altitude.

\subsubsection{Atlantic and Mediterranean Origin of Precipitation}

The deuterium excess values of precipitation increased as the cold season approached, particularly in the months of September and October. By analysing the deuterium excess values of precipitation, as was done by previous authors [32], it was possible to highlight that, in the warm season until September, precipitation formed from clouds coming from the Atlantic Ocean (with values up to 15\% [50]). In the late autumn (i.e., October for the study area), the main contribution to cloud formation was the Mediterranean Sea (with higher values up to 22\% [51]). In conclusion, the western Aosta Valley is located in an 
area with influences from two seas and is therefore susceptible to both qualitative and quantitative changes in the two different meteoric inputs, as was already proven for most of the Alpine area (Figure 13).

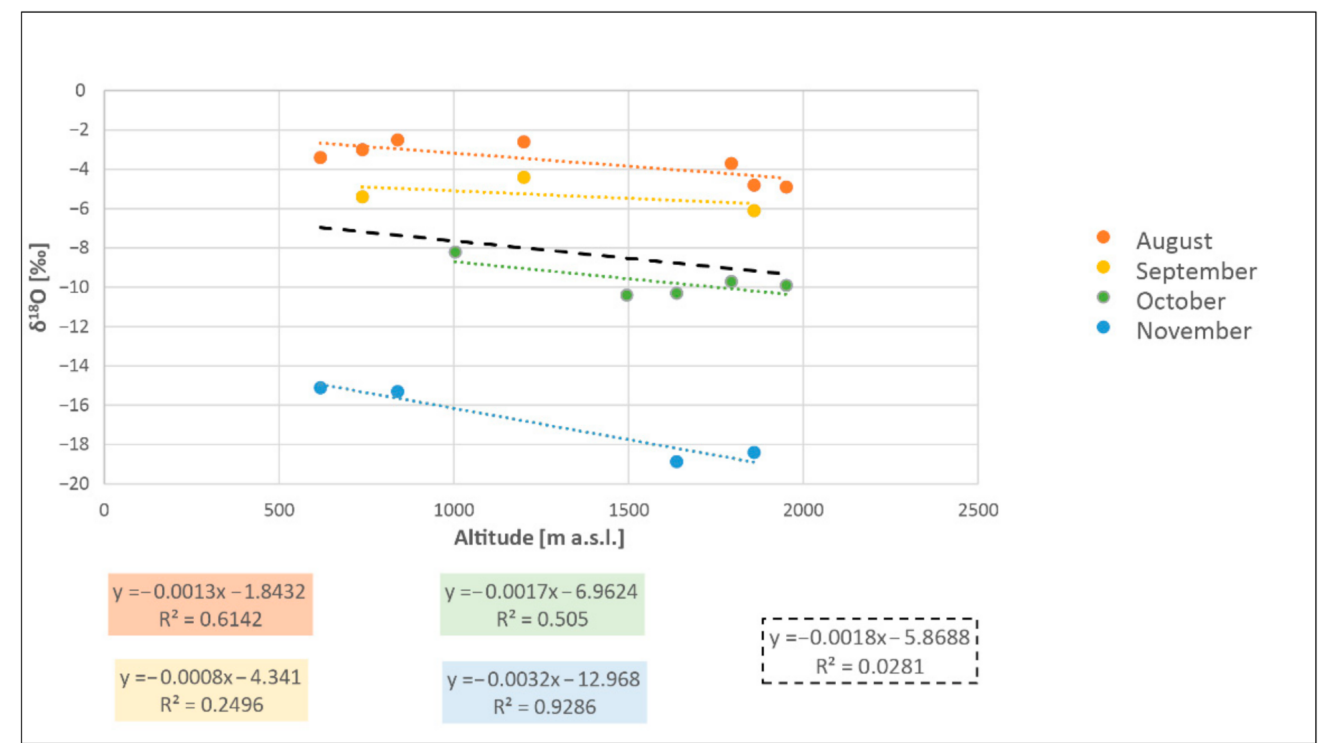

Figure 12. Precipitation $\delta^{18} \mathrm{O}$ values versus the altitude of the sampling location. The linear regression of the data series (dashed black line) allowed us to obtain an overall vertical isotopic gradient for the studied area. The coloured dashed lines represent linear regressions for August (red), September (yellow), October (green) and November (blue). Equations of the linear regression and $\mathrm{R}^{2}$ were reported for the single months and for the entire period.

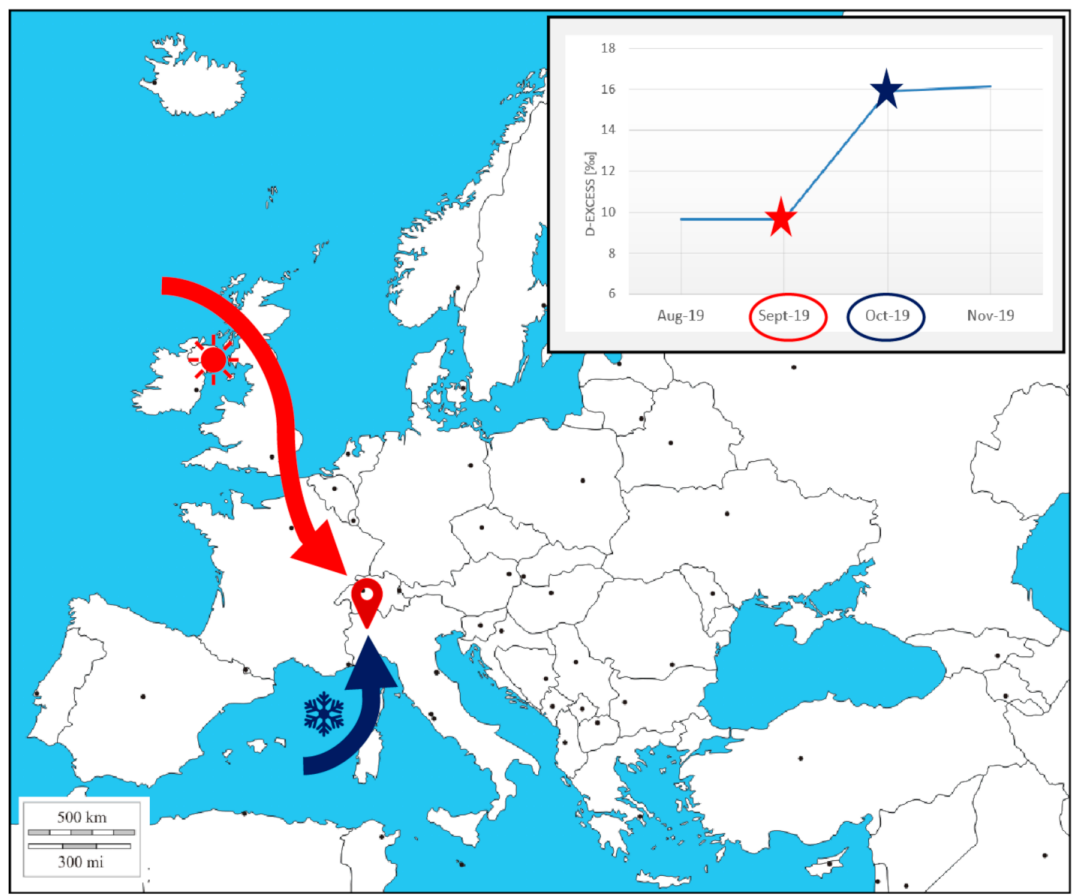

Figure 13. Path simulation of wet air masses based on deuterium excess data, which are plotted versus time in the top right corner of the figure.

\section{Conclusions and Future Developments}

This multidisciplinary approach to waters in the western Aosta Valley has demonstrated that deeper knowledge can be obtained through multiple analyses. 
This work highlighted that water quality depends on local conditions (i.e., aquifer lithology, water mixing into the aquifer, proximity to towns, contribution of snow melt and ice melt to groundwater recharge, amount of rain and, locally, season and altitude of the sampling location). However, interregional conditions (i.e., air pollution, glacier retreat, temperature modifications and general climate change) could also greatly affect the water.

More specifically, physical-chemical data obtained from the analysis of surface water, groundwater and precipitation allowed us to confirm the good quality status of waters in the study area according to the current national legislation (D.Lgs. 152/2006). In addition, these analyses allowed us to identify relationships between the studied parameters and the altitude, season, proximity to towns and local geology that directly influence water hydrochemical facies. Finally, it is possible to assume a relationship between atmospheric dust and the chemistry of precipitation. Such conditions, despite the necessity of further studies and insights, highlight the importance of studying air mass movements and reducing air pollution, not only in the region but also in bordering regions from which a larger amount of dust was detected above the Aosta Valley.

Moreover, stable isotopes of water, which were analysed in groundwater, surface water and precipitation, allowed us to formulate both the local meteoric water line and the vertical isotopic gradient of the western Aosta region. In addition, relevant mixing into the aquifers between melting waters and precipitation was observed. It is possible to conclude that, in the study area, water availability is not only linked to precipitation but also depends primarily on the water quantity stored in the form of snow and ice in glaciers, which cover the heads of the lateral valleys within the region. These ice masses have retreated significantly over recent decades due to climate change, and this situation could have important consequences on future aquifer recharge.

Finally, it was confirmed that the Aosta Valley region contributes to cloud formation from both the Atlantic Ocean and the Mediterranean Sea. Therefore, the region is susceptible to any qualitative and quantitative modifications of the two water inputs.

In conclusion, this research highlights the importance of implementing, developing and improving different analysis techniques applied to aquifer studies, because traditional study approaches are not always sufficient to achieve proper knowledge for the optimal and sustainable management of water resources.

An advanced hypothesis would require further chemical and isotopic investigations extended through time.

Additional analyses would be useful to investigate the relationships between air and water pollution and between human activity and water quality as well as relationships between climate change and temperature modification and, consequently, snow and ice fusion rates.

Author Contributions: Conceptualization, B.G., D.A.D.L. and M.L.; methodology, B.G., D.A.D.L. and M.L.; validation, B.G., D.A.D.L. and M.L.; formal analysis, B.G.; investigation, B.G.; data curation, B.G., C.C. and M.L.; writing—original draft preparation, B.G., M.L. and P.C.; writing—review and editing, B.G. and M.L.; supervision, D.A.D.L. All authors have read and agreed to the published version of the manuscript.

Funding: This research received no external funding.

Institutional Review Board Statement: Not applicable.

Informed Consent Statement: Not applicable.

Data Availability Statement: Data sharing not applicable.

Acknowledgments: We would like to thank Giulio Contri, Igor Torlai and Luca Stefanoli (Centro Funzionale Valle d'Aosta) for their assistance in the collection of rainfall. Moreover, we thank Henri Diémoz and Tiziana Magri (ARPA Valle d'Aosta) for their help in the analysis of aerosol pollution distribution.

Conflicts of Interest: The authors declare no conflict of interest. 


\section{References}

1. Konikow, L.F.; Kendy, E. Groundwater depletion: A global problem. Hydrogeol. J. 2005, 13, 317-320. [CrossRef]

2. Taylor, R.G.; Scanlon, B.; Döll, P.; Rodell, M.; Van Beek, R.; Wada, Y.; Longuevergne, L.; Leblanc, M.; Famiglietti, J.S.; Edmunds, M.; et al. Ground water and climate change. Nat. Clim. Chang. 2013, 3, 322-329. [CrossRef]

3. Gorelick, S.M.; Zheng, C. Global change and the groundwater management challenge. Water Resour. Res. 2015, 51, 3031-3051. [CrossRef]

4. Lasagna, M.; Mancini, S.; De Luca, D.A. Aquifer protection from overexploitation: Example of actions and mitigation activi-ties used in the Maggiore Valley (Asti Province, NW Italy). Geoingegneria Ambientale e Mineraria 2019, 156, 30-38.

5. Lasagna, M.; Ducci, D.; Sellerino, M.; Mancini, S.; De Luca, D.A. Meteorological Variability and Groundwater Quality: Examples in Different Hydrogeological Settings. Water 2020, 12, 1297. [CrossRef]

6. Department of Economic and Social Affairs Sustainable Development. Available online: https://sdgs.un.org/topics/water-andsanitation (accessed on 15 November 2020).

7. Alley, W.M.; Reilly, T.E.; Franke, O.L. Sustainability of Ground-Water Resources; US Geological Survey Circular 1186; USGS: Denver, CO, USA, 1999.

8. $\quad$ Bhaduri, A.; Bogardi, J.; Siddiqi, A.; Voigt, H.; Vörösmarty, C.; Pahl-Wostl, C.; Bunn, S.E.; Shrivastava, P.; Lawford, R.; Foster, S.; et al. Achieving Sustainable Development Goals from a Water Perspective. Front. Environ Sci. 2016, 4, 64. [CrossRef]

9. Dzhamalov, R.G.; Zlobina, V.L. Precipitation pollution effect on groundwater hydrochemical regime. Environ. Earth Sci. 1995, 25, 65-68. [CrossRef]

10. Barbieri, M. Isotopes in Hydrology and Hydrogeology. Water 2019, 11, 291. [CrossRef]

11. Regione Valle d'Aosta. Available online: http:/ / cf.regione.vda.it/i_giorni_piu.php (accessed on 15 November 2020).

12. Polino, R.; Dal Piaz, G.V.; Gosso, G. Tectonic erosion at the Adria margin and accretionary processes for the Cretaceous orogeny of the Alps. Mémoires de la Société Géologique de France (1833) 1990, 156, 345-367.

13. Lagabrielle, Y.; Lemoine, M. Alpine, Corsican and Apennine ophiolites: The slow-spreading ridge model. Comptes Rendus de l'Académie des Sci. Ser. IIA-Earth Planet. Sci. 1997, 325, 909-920. [CrossRef]

14. Gasco, I.; Gattiglio, M.; Borghi, A. Review of metamorphic and kinematic data from Internal Crystalline Massifs (Western Alps): PTt paths and exhumation history. J. Geodyn. 2013, 63, 1-19. [CrossRef]

15. Elter, G. La zona Pennidica dell'Alta e Media Valle D'Aosta e le Unità Limitrofe: Con 22 Figure, 1 tavola fuori testo e 1 Carta Tettonica alla Scala 1: 100 000; Società cooperativa tipografica: Padova, Italy, 1960.

16. Ellero, A.; Loprieno, A. Nappe stack of Piemonte-Ligurian units south of Aosta Valley: New evidence from Urtier Valley (Western Alps). Geol. J. 2018, 53, 1665-1684. [CrossRef]

17. Bousquet, R.; Engi, M.; Gosso, G.; Berger, A.; Spalla, M.I.; Zucali, M.; Goffè, B. Explanatory notes to the map: Metamorphic structure of the Alps in Central Alps. Mitt. Österr. Min. Ges. 2004, 149, 41-51.

18. Forno, M.G.; Comina, C.; Gattiglio, M.; Gianotti, F. Preservation of Quaternary sediments in DSGSD environments: The Mont Fallère case study (Aosta Val-ley, NW Italy). Alp. Mediterr. Quat. 2016, 29, 181-191.

19. Guillot, F.; Schaltegger, U.; Bertrand, J.-M.; Deloule, E.; Baudin, T. Zircon U-Pb geochronology of Ordovician magmatism in the polycyclic Ruitor Massif (Internal W Alps). Int. J. Earth Sci. 2016, 91, 964-978. [CrossRef]

20. Bertrand, J.M.; Pidgeon, R.T.; Leterrier, J.; Guillot, F.; Gasquet, G.; Gattiglio, M. SHRIMP and IDTIMS U-Pb zircon ages of the pre-Alpine basement in the Internal Western Alps (Savoy and Piemont). Schweiz. Mineral. Pet-Rographische Mitt. 2000, 80, 225-248.

21. Elter, G.; Elter, P. Carta Geologica Della Regione del Piccolo S. Bernardo (Versante Italiano); Note Illustrative; Litografia Artistica Cartografica: Firenze, Italy, 1965; p. 53.

22. Loprieno, A.; Bousquet, R.; Bucher, S.; Ceriani, S.; Torre, F.H.D.; Fügenschuh, B.; Schmid, S.M. The Valais units in Savoy (France): A key area for understanding the palaeogeography and the tectonic evolution of the Western Alps. Int. J. Earth Sci. 2010, 100, 963-992. [CrossRef]

23. Trumpy, R. Remarques sur la correlation des unites penniques externes entre la Savoie et le Valais et sur l'origine des nappes prealpines. Bsgf Earth Sci. Bull. 1955, 6, 217-231. [CrossRef]

24. RAVA. Progetti via 992 PRAE: Verifica E Aggiornamento Triennale del Piano Regionale Delle Attività Estrattive; Dipartimento Territorio Ed Ambiente: Aosta, Italy, 2012.

25. Leloup, P.H.; Arnaud, N.; Sobel, E.R.; Lacassin, R. Alpine Thermal and Structural Evolution of the Highest External Crystal-Line Massif: The Mont Blanc. Tectonics 2005, 24, TC4002. [CrossRef]

26. Rocco, R.; Santelli, E. Water Resources Management in Valle d'Aosta (Northwest of Italy). AQUA Mundi 2010, Am01013, 93-100.

27. ARPA Valle d'Aosta. Available online: https://www.arpa.vda.it/it/archivio-news/3246-monitoraggio-delle-acque-sotterranee\%E2\%80\%93-sintesi-anno-2019 (accessed on 15 November 2020).

28. Stefania, G.; Rotiroti, M.; Fumagalli, L.; Zanotti, C.; Bonomi, T. Numerical Modeling of Remediation Scenarios of a Groundwater Cr(VI) Plume in an Alpine Valley Aquifer. Geoscience 2018, 8, 209. [CrossRef]

29. De Luca, D.A.; Abdin, E.C.; Forno, M.G.; Gattiglio, M.; Gianotti, F.; Lasagna, M. The Montellina Spring as an Example of Water Circulation in an Alpine DSGSD Context (NW Italy). Water 2019, 11, 700. [CrossRef]

30. Giustini, F.; Brilli, M.; Patera, A. Mapping oxygen stable isotopes of precipitation in Italy. J. Hydrol. Reg. Stud. 2016, 8, 162-181. [CrossRef]

31. Longinelli, A.; Selmo, E. Isotopic composition of precipitation in Italy: A first overall map. J. Hydrol. 2003, 270, 75-88. 
32. Novel, J.P.; Ravello, M.; Dary, M.; Pollicini, F.; Zuppi, G.M. Contribution isotopique $\left({ }^{18} \mathrm{O},{ }^{2} \mathrm{H},{ }^{3} \mathrm{H}\right)$ à la compréhension des mécanismes d'écoulements des eaux de surface et des eaux souterraines en Vallée d'Aoste (Italie). Geogr. Fis. Dinam. Quat. 1995, 18, 315-319.

33. Novel, J.P.; Puig, J.M.; Zuppi, G.M.; Dray, M.; Dzikowski, M.; Jusserand, C.; Money, E.; Nicoud, G.; Parriaux, A.; Pollicini, F. Complexité des circulations dans l'aquifère alluvial de la plaine d'Aoste (Italie): Mise en évidence par l'hydrogéochimie. Eclogae Geol. Helv. 2002, 95, 323-331.

34. Vuillermoz, R. Idrogeologia del versante italiano del massiccio del Monte Bianco. Master's Thesis, University of Torino, Turin, Italy, 1993.

35. Alemani, P.; Bistacchi, A.; Bonetto, F.; Piazzardi, M.; Tognoni, A. Studi ed indagini per la definizione delle caratteristiche idrogeologiche dell'acquifero termale di Pré St. Didier (Ao). Acque Sotter. 1999, 63, 17-30.

36. Ravello, M. Bilancio dei Ghiacciai con il Metodo Isotopico. Master's Thesis, University of Torino, Turin, Italy, 1991. Unpublished.

37. Bolognini, D. Idrogeologia del Versante Italiano del Massiccio del Monte Bianco: Val Veny (Valle d'Aosta). Master's Thesis, University of Torino, Turin, Italy, 1993. Unpublished.

38. IAEA. Available online: http://www-naweb.iaea.org/napc/ih/documents/other/gnip_manual_v2.02_en_hq.pdf (accessed on 15 November 2020).

39. Merlivat, L.; Jouzel, J. Global climatic interpretation of the deuterium-oxygen 18 relationship for precipitation. J. Geophys. Res. Space Phys. 1979, 84, 5029-5033. [CrossRef]

40. Dansgaard, W. Stable isotopes in precipitation. Tellus 1964, 16, 436-468. [CrossRef]

41. Schoeller, H. Les Eaux Souterraines; Masson et Cie Éditeurs: Paris, France, 1962; p. 642.

42. Bucci, A.; Lasagna, M.; De Luca, D.A.; Acquaotta, F.; Barbero, D.; Fratianni, S. Time series analysis of underground temperature and evaluation of thermal properties in a test site of the Po plain (NW Italy). Environ. Earth Sci. 2020, 79, 1-15. [CrossRef]

43. Prinetti, F. Andar per sassi. Le Rocce Alpine fra Natura e Cultura; Musumeci Editore: Aosta, Italy, 2010.

44. Chabod, A.; Blanc, S. La montagna Abita Valsavarenche; IL Valico edizioni: Firenze, Italy, 2008; p. 192.

45. ARPA Valle d'Aosta. Available online: http://www.arpa.vda.it/it/aria/3045-mappe-concentrazioni-annuali2020 (accessed on 25 October 2020).

46. Diémoz, H.; Barnaba, F.; Magri, T.; Pession, G.; Dionisi, D.; Pittavino, S.; Tombolato, I.K.F.; Campanelli, M.; Della Ceca, L.S.; Hervo, M.; et al. Transport of Po Valley aerosol pollution to the northwestern Alps-Part 1: Phenomenology. Atmos. Chem. Phys. Discuss. 2019, 19, 3065-3095. [CrossRef]

47. Diémoz, H.; Gobbi, G.P.; Magri, T.; Pession, G.; Pittavino, S.; Tombolato, I.K.; Campanelli, M.; Barnaba, F. Transport of Po Valley aerosol pollution to the northwestern Alps-Part 2: Long-term impact on air quality. Atmos. Chem. Phys. 2019, 19, 10129-10160. [CrossRef]

48. Craig, H. Isotopic Variations in Meteoric Waters. Science 1961, 133, 1702-1703. [CrossRef] [PubMed]

49. Scandellari, F.; Penna, D. Gli isotopi stabili nell'acqua fra suolo, pianta e atmosfera. Italus Hortus 2017, 24, 51-67. [CrossRef]

50. Froehlich, K.; Gibson, J.J.; Aggarwal, P.K. Deuterium Excess in Precipitation and Its Climatological Significance; IAEA-CSP-13/P; IAEA: Vienna, Austria, 2002.

51. Gat, J.R.; Carmi, I. Evolution of the isotopic composition of atmospheric waters in the Mediterranean Sea area. J. Geophys. Res. Space Phys. 1970, 75, 3039-3048. [CrossRef] 